\title{
Closure Plan for the Area 3 Radioactive Waste Management Site at the Nevada Test Site
}

\author{
Prepared by \\ Natlonal Securlty TechnologlesLLe \\ Vision - Service - Pertnership \\ Prepared for \\ U.S. Department of Energy \\ National Nuclear Security Administration \\ Nevada Site Office \\ under Contract Number \\ DE-AC52-06NA25946
}

September 2007 


\title{
DISCLAIMER NOTICE
}

Reference herein to any specific commercial product, process, or service by trade name, trademark, manufacturer, or otherwise, does not necessarily constitute or imply its endorsement, recommendation, or favoring by the U. S. Government or any agency thereof.

Available for sale to the public, in paper, from:

\author{
U.S. Department of Commerce \\ National Technical Information Service \\ 5285 Port Royal Road \\ Springfield, VA 22161 \\ Phone: (800) 553-6847 \\ Fax: (703) 605-6900 \\ E-mail: orders@ntis.fedworld.gov \\ Online Ordering: http://www.ntis.gov/ordering.htm
}

Available electronically at http://www.osti.gov/bridge

Available for a processing fee to the U.S. Department of Energy and its contractors, in paper, from:

\author{
U.S. Department of Energy \\ Office of Scientific and Technical Information \\ P.O. Box 62 \\ Oak Ridge, TN 37831-0062 \\ Phone: (865) 576-8401 \\ Fax: (865) 576-5728 \\ E-mail: reports@adonis.osti.gov
}




\section{Closure Plan for the Area 3 Radioactive Waste Management Site at the Nevada Test Site}

Prepared by

\section{National Security TechnologiesLLe \\ Violon - Service - Portnershlp}

Prepared for

U.S. Department of Energy

National Nuclear Security Administration

Nevada Site Office under Contract Number

DE-AC52-06NA25946

September 2007 
This Page Intentionally Left Blank 


\section{EXECUTIVE SUMMARY}

The Area 3 Radioactive Waste Management Site (RMWS) at the Nevada Test Site (NTS) is managed and operated by National Security Technologies, LLC (NSTec) for the U.S. Department of Energy, National Nuclear Security Administration Nevada Site Office (NNSA/NSO). This document is the first update of the interim closure plan for the Area 3 RWMS, which was presented in the Integrated Closure and Monitoring Plan (ICMP) (DOE, 2005). The format and content of this plan follows the Format and Content Guide for U.S. Department of Energy Low-Level Waste Disposal Facility Closure Plans (DOE, 1999a).

The major updates to the plan include a new closure date, updated closure inventory, the new institutional control policy, and the Title II engineering cover design. The plan identifies the assumptions and regulatory requirements, describes the disposal sites and the physical environment in which they are located, presents the design of the closure cover, and defines the approach and schedule for both closing and monitoring the site.

The Area 3 RWMS accepts low-level waste (LLW) from across the DOE Complex in compliance with the NTS Waste Acceptance Criteria (NNSA/NSO, 2006). The Area 3 RWMS accepts both packaged and unpackaged unclassified bulk LLW for disposal in subsidence craters that resulted from deep underground tests of nuclear devices in the early 1960s.

The Area 3 RWMS covers 48 hectares (119 acres) and comprises seven subsidence craters U-3ax, U-3bl, U-3ah, U-3at, U-3bh, U-3az, and U-3bg. The area between craters U-3ax and U-3bl was excavated to form one large disposal unit (U-3ax/bl); the area between craters U-3ah and U-3at was also excavated to form another large disposal unit (U-3ah/at). Waste unit $\mathrm{U}-3 \mathrm{ax} / \mathrm{bl}$ is closed; waste units U-3ah/at and U-3bh are active; and the remaining craters, although currently undeveloped, are available for disposal of waste if required.

This plan specifically addresses the closure of the U-3ah/at and the U-3bh LLW units. A final closure cover has been placed on unit U-3ax/bl (Corrective Action Unit 110) at the Area 3 RWMS. Monolayer-evapotranspirative closure cover designs for the U-3ah/at and U-3bh units are provided in this plan. The current-design closure cover thickness is 3 meters (10 feet). The final design cover will have an optimized cover thickness, which is expected to be less than $3 \mathrm{~m}$ $(10 \mathrm{ft})$.

Although waste operations at the Area 3 RWMS have ceased at the end of June 2006, disposal capacity is available for future disposals at the U-3ah/at and U-3bh units. The Area 3 RWMS is expected to start closure activities in fiscal year 2025, which include the development of final performance assessment and composite analysis documents, closure plan, closure cover design for construction, cover construction, and initiation of the post-closure care and monitoring activities.

Current monitoring at the Area 3 RWMS includes monitoring the cover of the closed mixed waste unit U-3ax/bl as required by the Nevada Department of Environmental Protection, and others required under federal regulations and DOE orders. Monitoring data, collected via sensors and analysis of samples, are needed to evaluate radiation doses to the general public, for performance assessment maintenance, to demonstrate regulatory compliance, and to evaluate the actual performance of the RWMSs. Monitoring provides data to ensure the integrity and 
performance of waste disposal units. The monitoring program is designed to forewarn management and regulators of any failure and need for mitigating actions. The plan describes the program for monitoring direct radiation, air, vadose zone, biota, groundwater, meteorology, and subsidence. The requirements of post-closure cover maintenance and monitoring will be determined in the final closure plan. 


\section{TABLE OF CONTENTS}

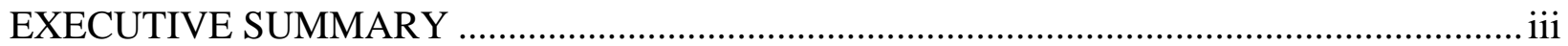

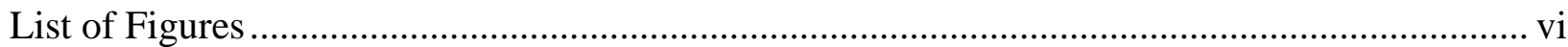

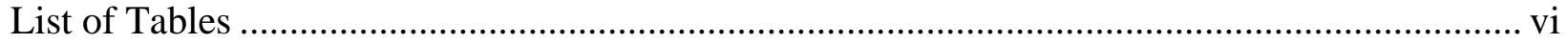

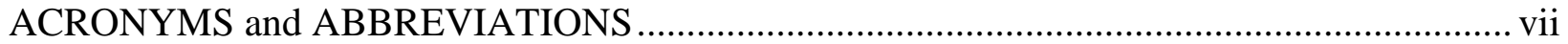

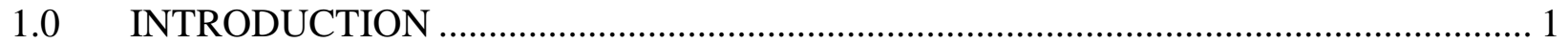

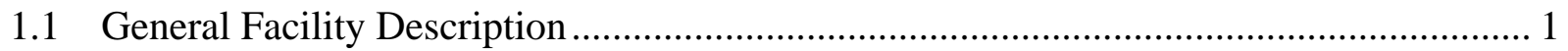

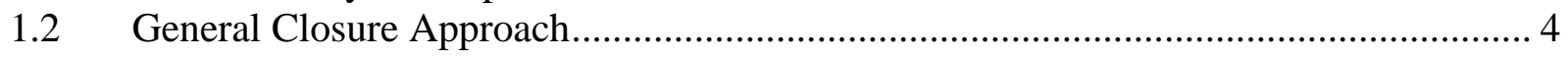

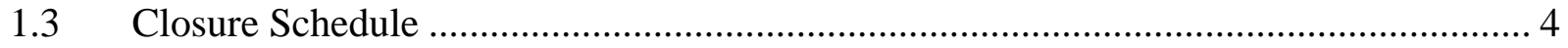

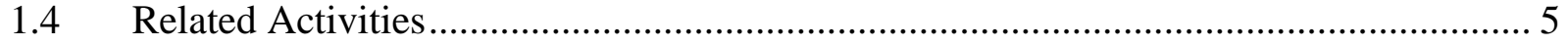

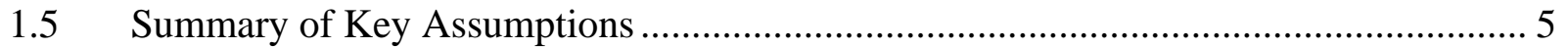

2.0 DISPOSAL FACILITY CHARACTERISTICS ...................................................... 7

2.1 Site Characteristics................................................................................... 7

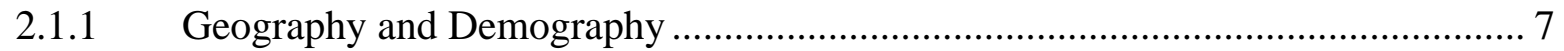

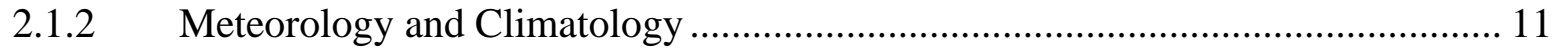

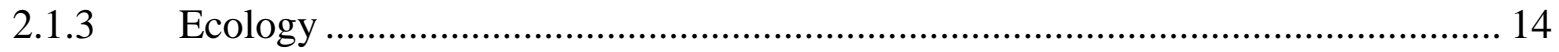

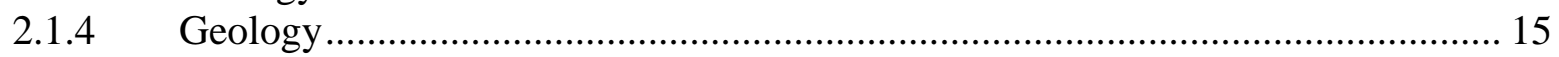

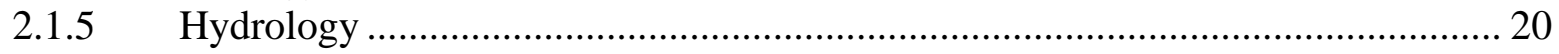

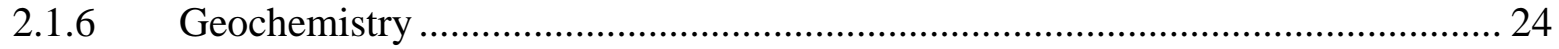

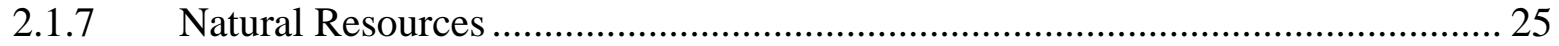

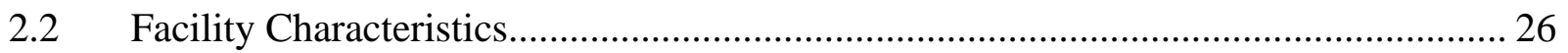

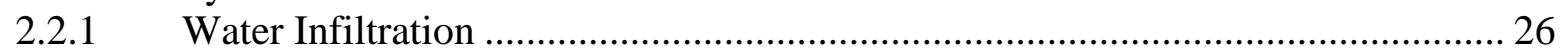

2.2.2 Disposal Unit Cover Integrity ............................................................ 27

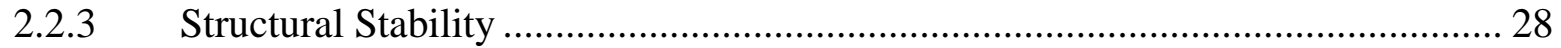

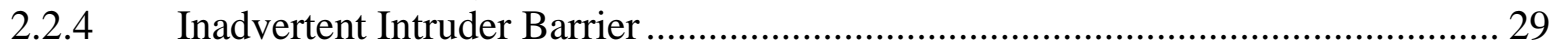

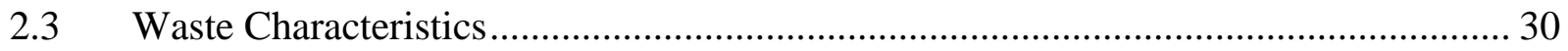

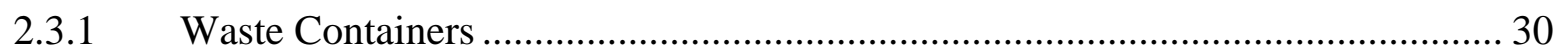

2.3.2 Treatment or Processing Prior to Disposal ................................................... 30

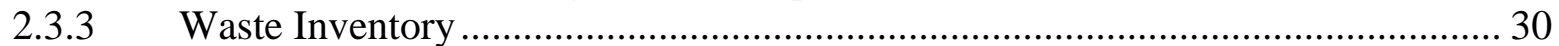

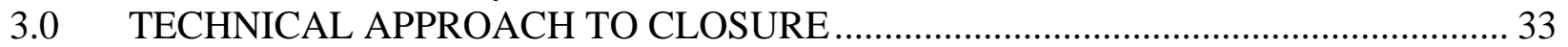

3.1 Compliance with Performance Objectives and Other Requirements ......................... 33

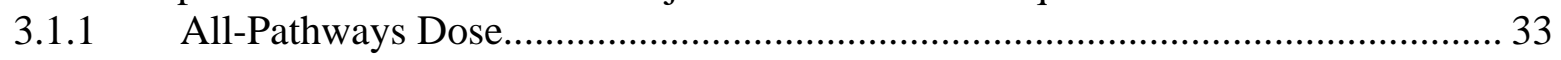

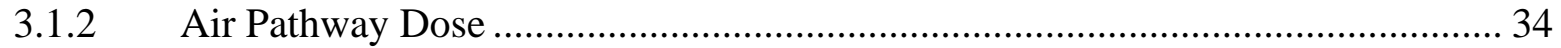

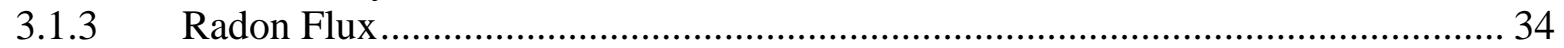

3.1.4 Other Requirements .................................................................................. 34

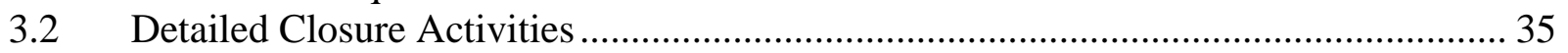

3.2.1 Operational/Interim Closure ...................................................................... 35

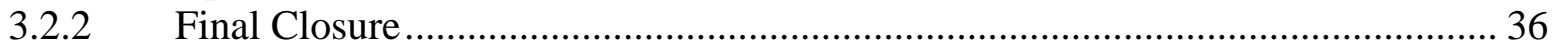

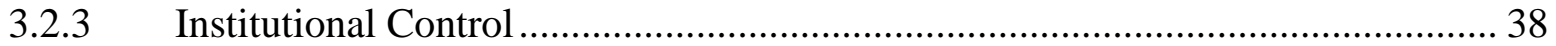

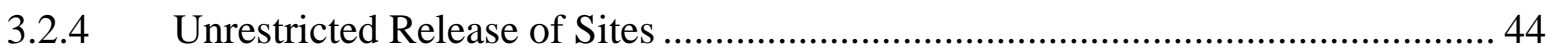

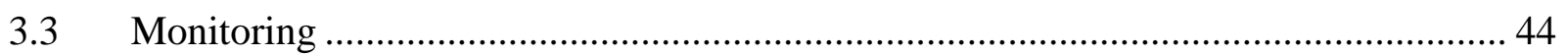

3.3.1 Operational/Interim Closure ................................................................... 45

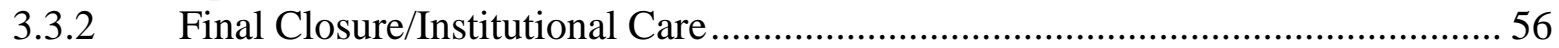

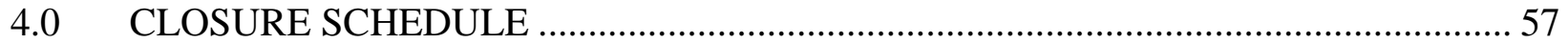

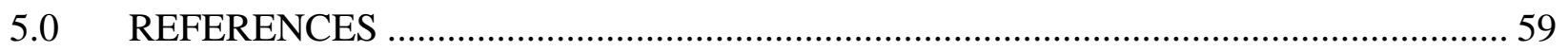

APPENDIX: Title II Engineering Cover Design..................................................... Appendix-1 


\section{List of Figures}

Figure 2.1 Location Map.................................................................................................... 2

Figure 2.2 Area 3 Radioactive Waste Management Site ...................................................... 3

Figure 3.1 Underground Test Area Corrective Action Units............................................... 8

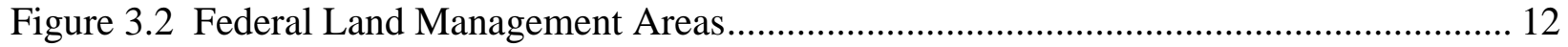

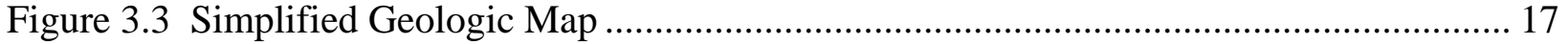

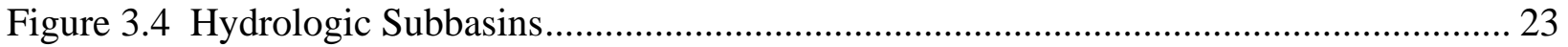

Figure 3.5 Conceptual Model of Flow and Transport........................................................... 27

Figure 4.1 Monitoring Locations at the Area 3 RWMS .................................................... 48

\section{List of Tables}

Table 4.1 Performance objectives and results of the Area 3 RWMS Performance Assessment 33

Table 4.2 Monitoring activities at the Area 3 Radioactive Waste Management Site 46 


\section{ACRONYMS and ABBREVIATIONS}

\begin{tabular}{|c|c|}
\hline AA & alluvial aquifer \\
\hline ac & acre(s) \\
\hline ASTM & American Society for Testing and Materials \\
\hline $\mathrm{Bq} / \mathrm{m}^{2} / \mathrm{s}$ & Becquerel per square meter per second \\
\hline $\mathrm{BN}$ & Bechtel Nevada \\
\hline $\mathrm{C}$ & Celsius \\
\hline CA & Composite Analysis \\
\hline CADD & Corrective Action Decision Document \\
\hline CAU & Corrective Action Unit \\
\hline CFR & Code of Federal Regulations \\
\hline $\mathrm{Ci}$ & curie \\
\hline $\mathrm{cm}$ & centimeter(s) \\
\hline DAS & Disposal Authorization Statement \\
\hline $\mathrm{DOE} / \mathrm{HQ}$ & U.S. Department of Energy/Headquarters \\
\hline $\mathrm{DOE} / \mathrm{NV}$ & U.S. Department of Energy/Nevada Operations Office \\
\hline DQO & Data Quality Objectives \\
\hline DVRFS & Death Valley Regional Flow System \\
\hline ER & Environmental Restoration \\
\hline ETLD & environmental thermoluminescent dosimeter \\
\hline EPA & U.S. Environmental Protection Agency \\
\hline ET & evapotranspiration \\
\hline $\mathrm{F}$ & Fahrenheit \\
\hline FFACO & $\begin{array}{l}\text { Federal Facilities Agreement and Consent Order } \\
\text { feet }\end{array}$ \\
\hline $\mathrm{ft}^{3}$ & cubic feet \\
\hline FY & fiscal year \\
\hline g & standard acceleration of gravity \\
\hline GCD & Greater Confinement Disposal \\
\hline ha & hectares \\
\hline $\mathrm{HGU}$ & hydrogeologic unit \\
\hline HSU & hydrostratigraphic unit \\
\hline HWSU & Hazardous Waste Storage Unit \\
\hline ICMP & Integrated Closure and Monitoring Plan \\
\hline IHI & inadvertent human intrusion \\
\hline in. & inch(es) \\
\hline $\mathrm{km}$ & kilometers \\
\hline $\mathrm{km}^{2}$ & square kilometers \\
\hline LANL & Los Alamos National Laboratory \\
\hline LCA & Lower Carbonate Aquifer \\
\hline
\end{tabular}




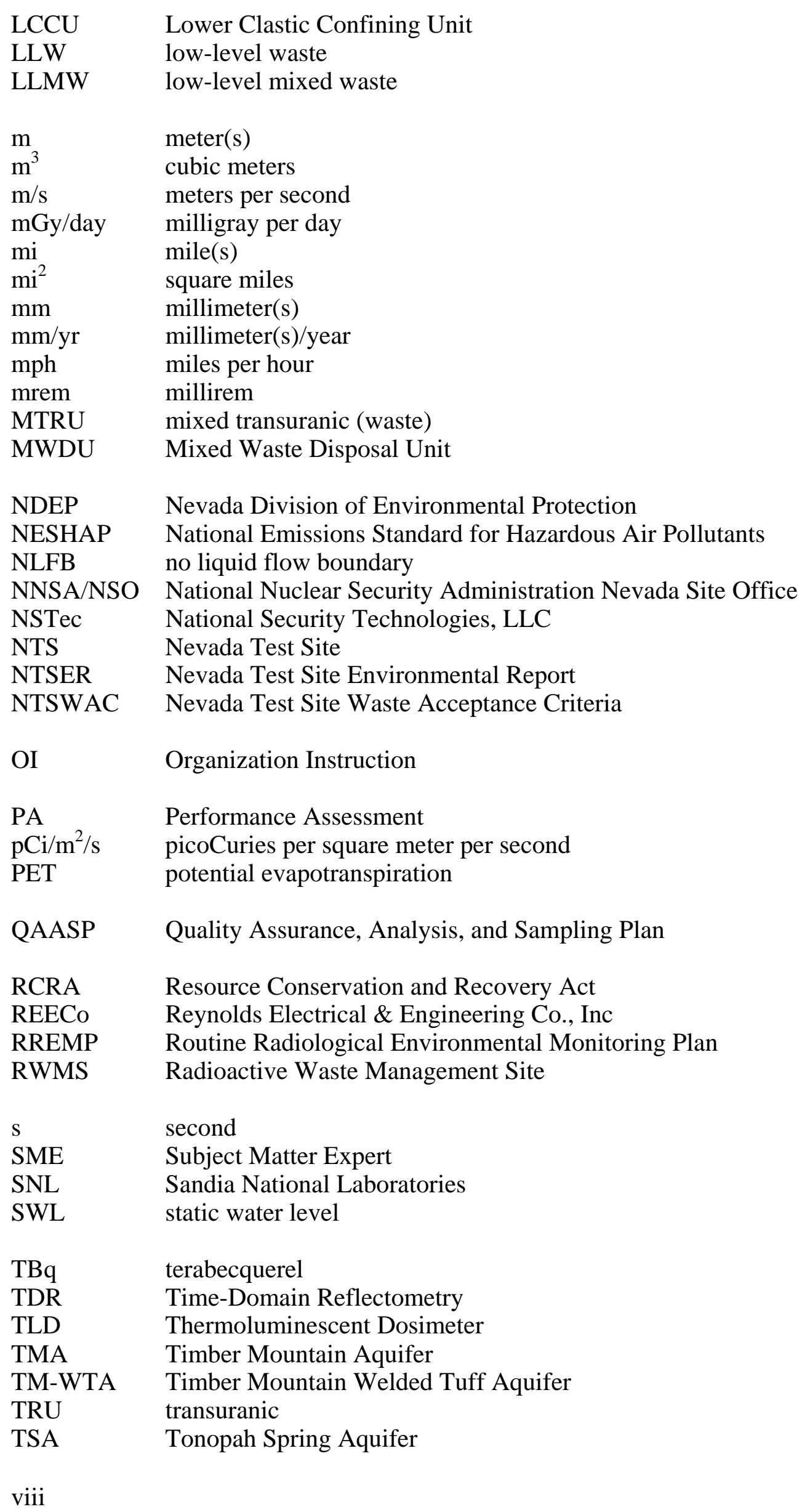


UGTA Underground Test Area

USGS U.S. Geological Survey

WIPP Waste Isolation Pilot Plant

WMD Waste Management Department (NNSA/NSO)

yr year 
This Page Intentionally Left Blank 


\subsection{INTRODUCTION}

The Area 3 Radioactive Waste Management Site (RMWS) at the Nevada Test Site (NTS) is managed and operated by National Security Technologies, LLC (NSTec) for the U.S. Department of Energy (DOE), National Nuclear Security Administration Nevada Site Office (NNSA/NSO). This document is the first update of the interim closure plan for the Area 3 RWMS, which was presented in the Integrated Closure and Monitoring Plan (ICMP) (DOE, 2005). The format and content of this plan follows the Format and Content Guide for U.S. Department of Energy Low-Level Waste Disposal Facility Closure Plans (DOE, 1999a).

DOE M435.1-1 IV.Q.10(a) requires that closure plans "be updated as required during the operational life of the facility." Changes in the closure schedule, the closure waste inventory, and the NNSA/NSO's institutional control policy warrant this update. The plan also includes Title II (85 percent complete) engineering design of the closure covers for the active units U-3ah/at and U-3bh. This updated plan identifies the assumptions and regulatory requirements, describes the disposal sites and the physical environment in which they are located, describes and presents the design of the closure covers, and presents the on-going monitoring activities.

\subsection{General Facility Description}

The Area 3 RWMS covers an area of 48 hectares (ha) (119 acres [ac]), approximately 45 kilometers (km) (28 miles [mi]) northwest of Mercury, Nevada, in the east-central part of Yucca Flat, in the northeast part of the NTS (Figure 1.1). Yucca Flat was the site of hundreds of nuclear tests conducted from the 1950s until the United States moratorium on nuclear testing in 1992. Underground testing formed surface subsidence craters and modified the natural topography. Atmospheric testing left areas of surface residual contamination by radionuclides. DOE established the Area 3 RWMS in the late 1960s primarily to receive bulk waste from the clean up of atmospheric test sites at the NTS. The Area 3 RWMS facility encompasses seven collapse sinks (craters) created by deep underground detonations in the early 1960s: U-3ax, U-3bl, U-3ah, U-3at, U-3bh, U-3az, and U-3bg (Figure 1.2). Test site U-3bm is also within the facility boundary but did not produce a significant subsidence crater. U-3bm is at the southern edge of the facility far from active waste operations.

Five of the craters within the Area 3 RWMS were developed to form three waste disposal units. The alluvium between subsidence craters U-3ax and U-3bl was excavated to form a single large disposal unit (U-3ax/bl). Similarly, the alluvium between craters U-3ah and U-3at was excavated to form a disposal unit (U-3ah/at). 


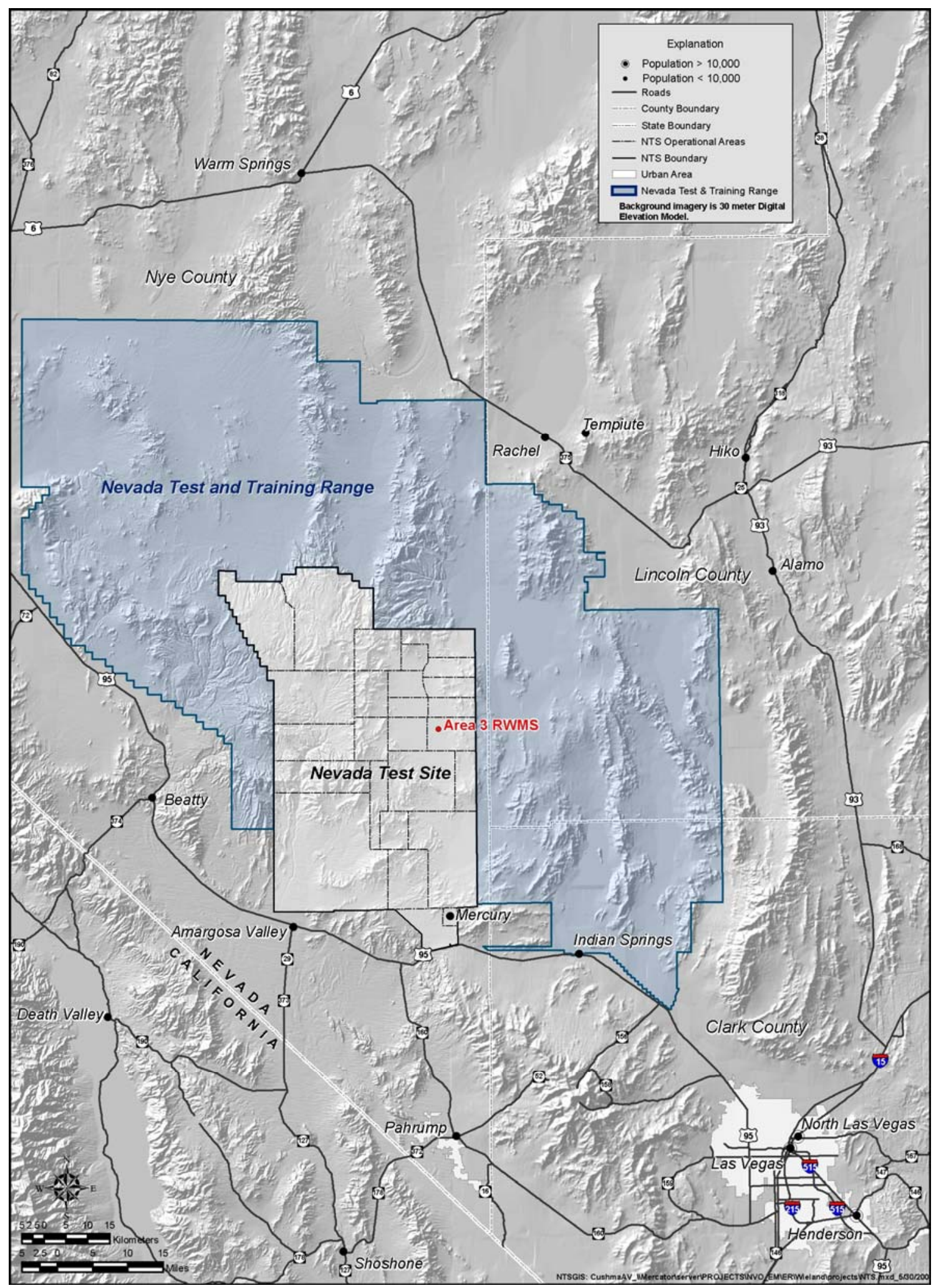

Figure 1.1 Location Map of the Area 3 Radioactive Waste Management Site within the Nevada Test Site in southern Nevada. 


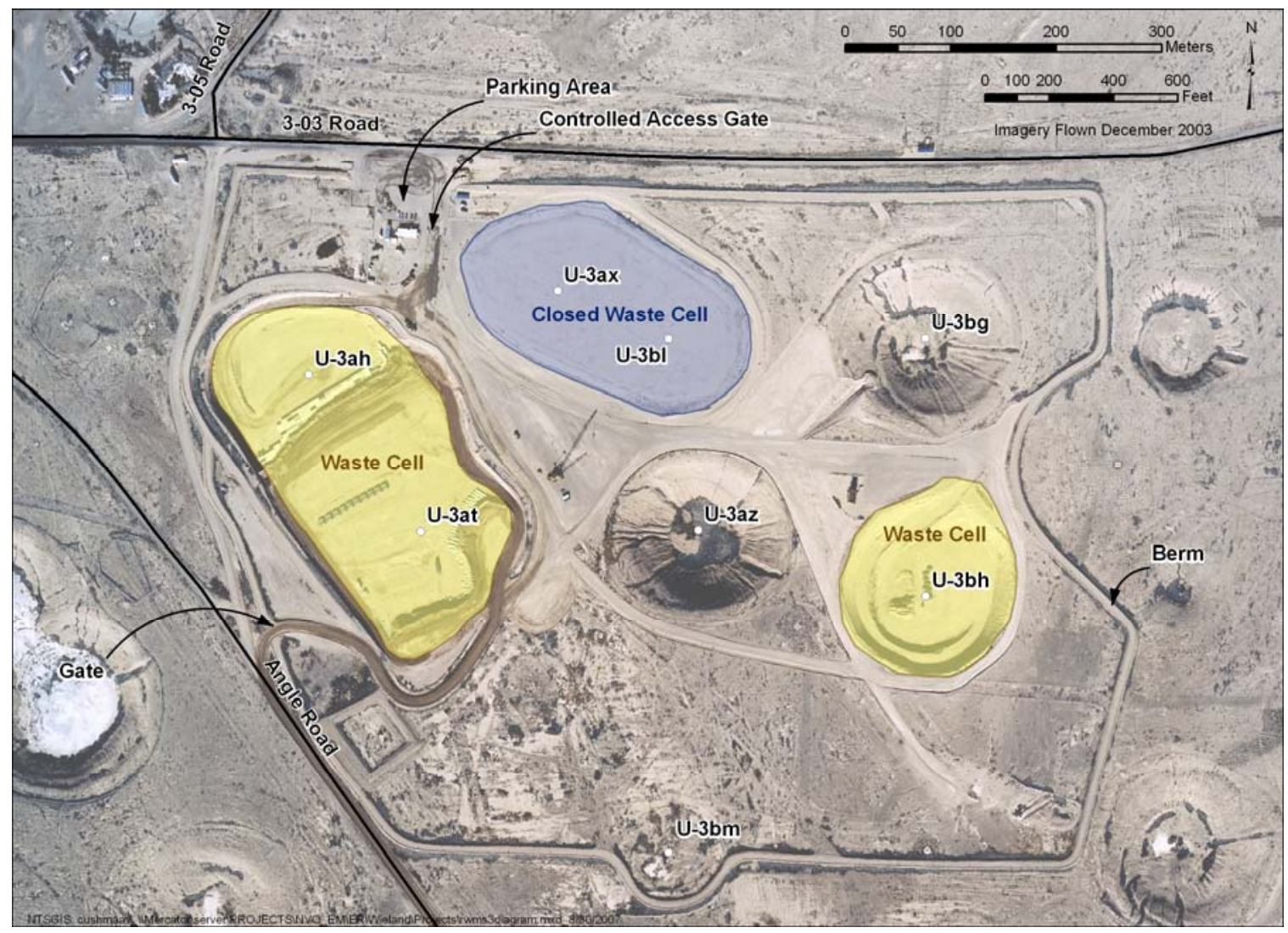

Figure 1.2 Area 3 Radioactive Waste Management Site

U-3ax/bl received unclassified low level waste (LLW) and potential low level mixed waste (LLMW) from 1968 to 1987. NNSA/NSO closed U-3ax/bl in 2000 with a monolayer evapotranspirative cover under the Federal Facility Agreement and Consent Order (FFACO) between the Nevada Division of Environmental Protection (NDEP) and DOE.

The active cells, U-3ah/at and U-3bh, accept unclassified LLW. Disposal began at U-3ah/at in 1988 and at U-3bh in 1997. Waste disposal ceased in these units in 2006; however, based on anticipated future NTS LLW receipts, these active cells will remain operational till fiscal year (FY) 2025. Craters U-3az and U-3bg are undeveloped but potentially available for future disposal of waste.

The Area 3 RWMS is an access-controlled facility with a wire fence around it. Earthen berms surround most of the facility to help mitigate potential flooding. The principal entrance to the RWMS is from the 03-03 Road on the north side of the facility. Waste management and radioactivity control personnel are deployed as needed to process receipts. A locking gate controls vehicular access to the waste disposal units.

A secondary entrance on the west side of the facility, off of Angle Road, exists for use by trucks hauling clean cover soil from the Area 3 borrow pit. A locking rope gate limits vehicular access at this entrance. 


\subsection{General Closure Approach}

The closure plan for the Area 3 RWMS follows DOE Order O 435.1 and DOE M435.1. Area 3 RWMS closure will be conducted in the two phases: operational closure, and final closure. Operational closure will be conducted during the operational period as disposal units are filled. Operational covers of native alluvial soil are placed on the filled units to minimize infiltration, facilitate operations, promote worker safety, and prepare the facility for final closure. After the U-3ah/at and the U-3bh units are full, they would be closed with operational covers. As need arises, other units will be developed to utilize the available disposal areas within the Area 3 RWMS. Final closure of the U-3ax/bl, U3-bh, and future potential units is tentatively scheduled to take place during 2025-2030.

Final closure activities for waste disposal units at the Area 3 RWMS will include the development of a final closure plan, a final closure cover design, final performance assessment (PA) and composite analysis (CA) documents, construction of the closure covers, and the initiation of the post-closure monitoring activities. The final closure covers for each disposal unit will be essentially the same as the Title II engineering design (85 percent complete design) presented in this plan for the U-3ah/at and the U-3bh units.

Final designs will include optimization of cover thickness through formal cost-benefit analysis. Final closure is primarily intended to minimize infiltration, attenuate radon flux, and minimize release of radionuclides by plant and burrowing animal activities during the post-closure compliance period.

Post-closure care and monitoring for the U-3ax/bl unit, which contains hazardous constituents and pre-1988 LLW, closed as a FFACO site, will continue to follow guidance in Title 40 Code of Federal Regulations (CFR) 264 Subpart N, and under the conditions set by NDEP. Monitoring is currently conducted at the Area 3 RWMS to satisfy regulatory requirements; ensure the integrity of covers over waste disposal units; sufficiently forewarn management and regulators of any need for mitigating actions, and record the utility of such actions; and provide data for routine maintenance of the PAs and CAs. Review of monitoring data for maintenance of the PAs and CAs is an iterative process that ultimately will dictate which monitoring data should continue to be collected and which monitoring data are no longer required for post-closure monitoring.

This plan describes the program for monitoring direct radiation, air, vadose zone, biota, groundwater, meteorology, and subsidence at the Area 3 RWMS during the operational closure period (current).

\subsection{Closure Schedule}

As operations continue at the Area 3 RWMS, this closure plan will be updated to reflect the most current operational features that must be considered during closure. The schedule for final 
closure of the facility will be developed in FY 2025. A schedule for post-closure monitoring and maintenance activities will also be developed as part of the final closure plan. Monitoring for the closed mixed-waste unit U-3ax/bl will continue for a time period according to conditions negotiated with the NDEP.

\subsection{Related Activities}

The PA Maintenance Program (NSTec, 2007a) has been tracking and resolving minor and secondary issues identified in the Disposal Authorization Statement (DAS) for the Area 3 RWMS (DOE, 2002). These issues include the inconsistencies in conceptual models and models implemented in the PAs/CAs of the Area 5 RWMS and the Area 3 RWMS, conducting site monitoring and characterization to increase confidence in the results of the PAs, periodic assessment of changes in potentially interactive sources impacting the CA results, and periodic assessment of land use restrictions and associated impacts on the CA results. The Area 3 RWMS DAS also calls for a future revision of the CA that incorporates the dose from the Underground Test Areas (UGTAs) within Yucca Flat.

The resolutions of these issues are reported in the PA/CA annual summary reports (NSTec, 2007d). NNSA/NSO developed probabilistic PA/CA models using the GoldSim ${ }^{\circledR}$ platform to address these issues and evaluate their impacts on the PAs/CAs. The PA Maintenance Program will optimize the cover thickness, utilizing the latest version of the Area 3 RWMS GoldSim ${ }^{\circledR}$ model with the latest closure inventory.

Environmental monitoring at the Area 3 RWMS is ongoing. Monitoring of the vadose zone at the U-3ax/bl cover and at the drainage lysimeters will continue to provide data essential for the evaluation of the long-term performance of the closure covers, and validate the assumptions about the closure cover thickness and the conceptual model of no groundwater pathway at the Area 3 RWMS.

Environmental restoration activities associated with two categories of Corrective Action Units (CAUs), the Soil Sites and the UGTA sites in Yucca Flat, are in progress. The results of these activities directly impact the assumptions of the Area 3 RWMS CA. The member of public dose in the CA incorporated the dose due to releases from about 30 soil sites within Yucca Flat and Plutonium Valley. It was assumed that residual radioactivity at theses soil sites will not need further clean up. Groundwater dose from the UGTA sources will be incorporated into the CA when the UGTA groundwater modeling in Yucca Flat is complete. As reported in the 2006 Annual Summary Report, the results of the flow and transport model that will aid in determining the 1,000-year groundwater contaminant boundaries for Yucca Flat are not expected until FY 2020 (NSTec, 2007d).

\subsection{Summary of Key Assumptions}

Assumptions related to closure and monitoring of the Area 3 RWMS are given below: 
- Funding will be available to complete closure-related activities at the scheduled times.

- Closure of all disposal units within the Area 3 RWMS, regardless of waste type, will be included in the NNSA/NSO WMD baseline.

- Activities related to final closure of the Area 3 RWMS will be under the management and technical direction of the NNSA/NSO WMD.

- The NNSA/NSO will approve all documents required for final closure of all disposal units at the Area 3 RWMS.

- Final closure activities at the Area 3 RWMS will start in FY 2025.

- No waste will be accepted in the current disposal areas after FY 2025.

- Operational environmental monitoring will continue through FY 2025 according to this plan.

- Environmental monitoring will continue after FY 20025 under long-term surveillance and maintenance, in the yet to be developed final closure plan. 


\subsection{DISPOSAL FACILITY CHARACTERISTICS}

The geography, demographics, and other physical characteristics of the NTS, Yucca Flat, and surrounding areas are collectively important to the RWMS, in terms of meeting the performance objectives defined in DOE M 435.1-1.

\subsection{Site Characteristics}

\subsubsection{Geography and Demography}

\subsubsection{Disposal Site Location}

The Area 3 RWMS covers 48 ha (119 ac) and is approximately $45 \mathrm{~km}$ (28 mi) northwest of Mercury, Nevada, in the east-central part of Yucca Flat, in the northeast part of the NTS (Figure 1.1).

The NTS, located in Nye County, Nevada, $104 \mathrm{~km}$ (65 mi) northwest of Las Vegas, comprises approximately 3,561 square kilometers $\left(\mathrm{km}^{2}\right)\left(1,375\right.$ square miles [mi $\left.\left.{ }^{2}\right]\right)$ of land reserved to the jurisdiction of the DOE under four land withdrawals (DOE, 1996). The primary use of the NTS between 1951 and 1992 was atmospheric and underground testing of nuclear weapons. Since 1992, subcritical experiments and other defense-related and nondefense-related activities have been and continue to be conducted at the NTS. Mercury, in the southeast corner of the NTS, is the primary support facility for the NTS. Other, smaller communities, including Amargosa Valley, Lathrop Wells, and Indian Springs, are also present within a few tens of km (tens of mi) of the NTS, along the U.S. Highway 95 corridor (Figure 1.1). The primary valleys on the NTS are Yucca Flat, Frenchman Flat, and Jackass Flats. Yucca Flat is in the northeast part of the NTS, Frenchman Flat is in the southeast part of the NTS, and Jackass Flats is in the southwest part of the NTS.

Yucca Flat is an elongated, sediment-filled basin that trends roughly north-south; the long axis is approximately $27 \mathrm{~km}(17 \mathrm{mi})$ and the short axis is approximately $16 \mathrm{~km}(10 \mathrm{mi})$. Yucca Flat is bounded by Quartzite Ridge and Rainier Mesa on the north, the Halfpint Range on the east, the Massachusetts Mountains and Control Point Hills on the south, and Mine Mountain and the Eleana Range on the west. The Yucca Flat basin slopes from the north at an elevation of approximately 1,402 $\mathrm{m}$ (4,600 ft) to the south toward Yucca Playa, the lowest part of the basin at an elevation of approximately 1,189 m (3,901 ft). Yucca Flat was one of four primary nuclear test areas and is essentially marked with subsidence craters along the entire length of the valley (Figure 2.1). 


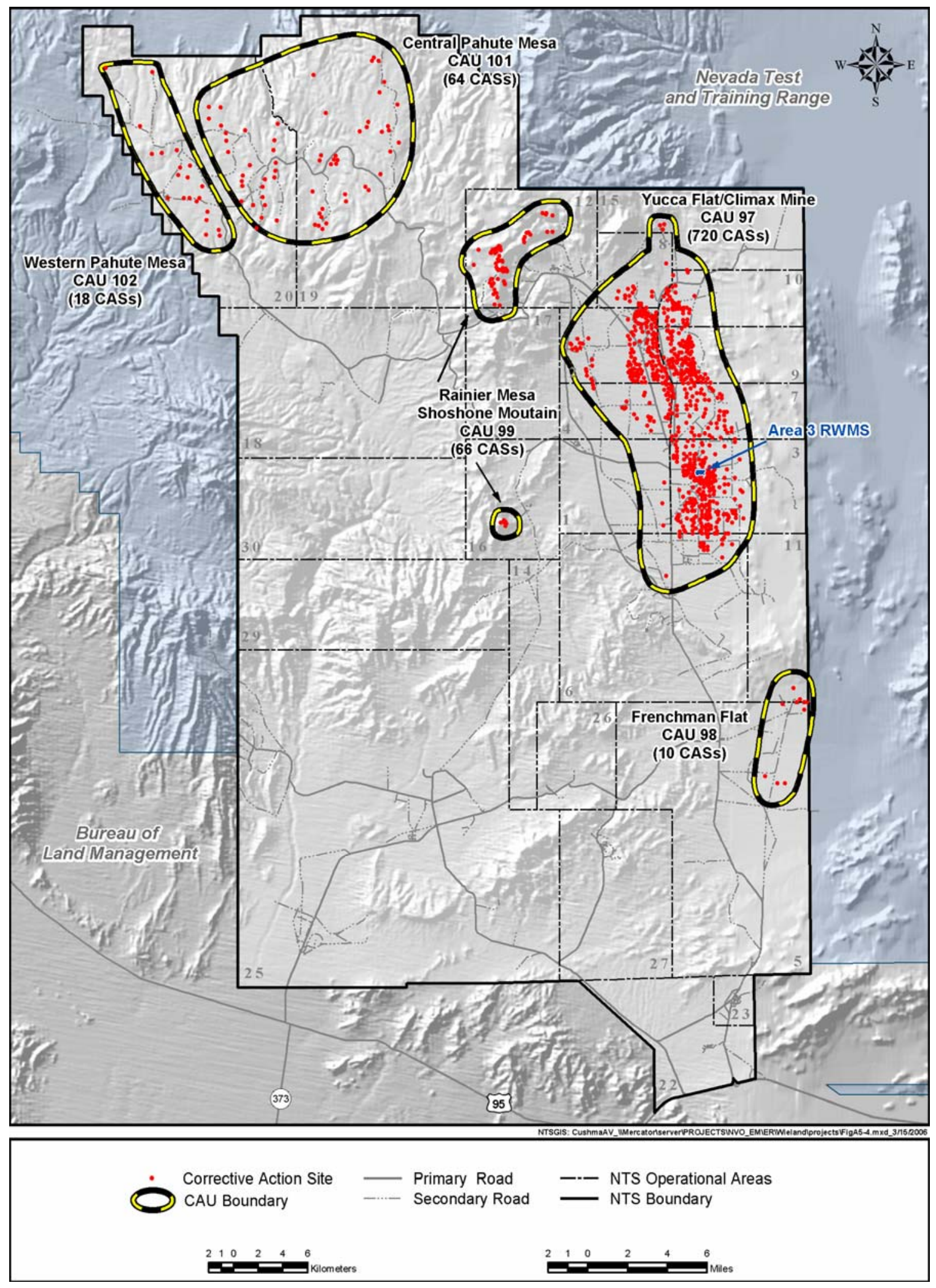

Figure 2.1 Underground Test Area Corrective Action Units 


\subsubsection{Disposal Site Description}

The first documented disposal at the Area 3 RWMS was in U-3ax crater on July 30, 1968 (REECo, 1968). Debris and soil contaminated by nuclear-device tests in the 1950s and early 1960s were collected and placed in the bottom of the crater (REECo, 1980). The Area 3 RWMS was established formally in 1978 with the advent of the NTS Waste Management Program.

In 1984, when the bottom of U-3ax crater was level with the bottom of adjacent U-3bl crater, the area between the craters was excavated, and disposal of contaminated debris and soil continued in the enlarged disposal unit. In 1985, cargo containers were disposed in the excavated area between the two craters, and in 1987 various sized containers were disposed in the upper part of U-3bl. An operational cover, nominally about $1.5 \mathrm{~m}$ (5 ft) thick (BN, 1999), was placed over U-3ax/bl after disposal operations stopped in 1987. A final closure cover was placed over $\mathrm{U}-3 \mathrm{ax} / \mathrm{bl}$ in 2001. About 80 percent of the waste disposed in $\mathrm{U}-3 \mathrm{ax} / \mathrm{bl}$ is contaminated debris and soil, and about half of this waste is soil. Low-level mixed waste (LLMW) also was disposed in U-3ax/bl (Elletson and Johnejack, 1995). The U-3ax/bl unit, CAU 110, was closed in accordance with the Resource Conservation and Recovery Act (RCRA) Permit NEV HW009 and the FFACO.

Disposal of contaminated debris and soil from continued cleanup of atmospheric nuclear test areas was moved to U-3at crater in 1988. Two tiers of unpackaged waste were placed in the crater over a period of approximately one year. As at U-3ax/bl, the area between crater U-3at and adjacent crater U-3ah was then excavated to expand the volume for waste disposal. The resulting waste disposal unit is designated U-3ah/at. From 1989 to present, four additional tiers of waste in cargo containers, primarily from offsite generators, have been disposed in U-3ah/at. Soft-sided packages of plutonium-contaminated soil from cleanup of safety shots at the Tonopah Test Range north of the NTS also have been disposed in U-3ah/at since 1997. The disposal unit has sufficient remaining volume for at most one tier of waste.

Unpackaged bulk waste and plutonium-contaminated soil and other waste in soft-sided packages have been disposed in disposal cell U-3bh since 1997. Disposal is anticipated to continue until the cell is full unless unforeseen conditions require closure cover prior the cell being filled completely. Disposed waste soil is covered with uncontaminated soil to ensure that contamination is not spread inadvertently.

\subsection{Disposal Operations}

Waste to be disposed at the Area 3 RWMS is transported on trucks. Upon arrival, shipping documents are checked and trucks are inspected both visually and with instrumentation to ensure that there is no leakage of contaminated materials from the containers. When cleared, the containers are off-loaded and placed in the appropriate area of the disposal unit (depending on whether the waste is in cargo containers, soft-sided packages, or is unpackaged). The location of the waste in the unit is recorded and tracked. 


\subsection{Ancillary Facilities}

The only structures at the Area 3 RWMS are an office trailer and a change trailer that are manned only during disposal operations. All other functions are supported by facilities at the Area 5 RWMS.

\subsubsection{Population Distribution}

Native Americans were the first to use the lands now within the NTS. The Shoshone lived at springs in the northern NTS and the Paiutes lived at springs in the southern NTS. Later, early settlers established cattle ranches and wild horse capture operations at local springs (Reno and Pippin, 1985). Mining operations have occurred on the NTS at the Oak Spring District, Mine Mountain District, and Wahmonie District (Reno and Pippin, 1985). In 1928, Cane Spring supported the 1,500-person mining community of Wahmonie (Allred et al., 1963).

The southwestern United States was very sparsely populated when the Nevada Proving Ground (later renamed the NTS) was established in 1951, to provide a continental location for testing nuclear devices. Although the Nevada population has grown significantly and continues to grow rapidly, the population continues to be highly concentrated in a few urban areas far from the NTS. The population distribution today is partly attributable to the limited availability of private developable land and the limited availability of economic mineral, water, and other resources.

Population density is sparse near the NTS and potential population growth in Nye County is constrained by vast federal land reserves. The Nevada Test and Training Range (NTTR), Tonopah Test Range, and NTS federal reserves form a contiguous access-controlled federal reserve encompassing approximately $14,200 \mathrm{~km}^{2}\left(5,483 \mathrm{mi}^{2}\right)$ of land. The Bureau of Land Management (BLM), Fish and Wildlife Service, and National Park Service (NPS) also control large land areas in Southern Nevada and Southern California with constraints on the types of access and development activities.

Amargosa Valley, located $3.2 \mathrm{~km}(2 \mathrm{mi})$ south of the southwestern corner of the NTS, is the nearest population center to the NTS. According to estimates prepared by the Nevada State Demographer http://www.nsbdc.org/demographer/pubs/images/NVpopul05.pdf) the estimated population of Amargosa in 2005 was 1,383. Other small rural population centers near the NTS are Beatty and Indian Springs.

The Nevada State Demographer estimated the population of Nye County in 2005 was 41,302. Much of the private developable land is within Pahrump Valley. Pahrump, located approximately $64 \mathrm{~km}$ (40 mi) from the NTS, is the largest community in Nye County. In 2005, the population of Pahrump (at 33,241) accounted for approximately 80 percent of the Nye County population.

A 1994 survey indicated 90 percent of the NTS workforce resided in Clark County, 7 percent resided in Nye County, and the remaining 3 percent resided in other counties or states (DOE, 
1996). Although a more recent survey is not available, current percentages are likely similar to those of the 1994 survey. Estimates prepared by the Nevada State Demographer (http://www.nsbdc.org/demographer/pubs/images/NVpopul05.pdf) showed that in 2005, the population of Clark County was 1,796,380, with the majority of residents living in the Las Vegas Valley.

Las Vegas offers primarily employment associated with gaming and construction industries, and has become a preferred retirement city. Amargosa Valley offers ranching and agriculture. Pahrump is a preferred retirement area and continues to serve as a bedroom community for Las Vegas and the NTS. The population of Beatty is largely supported by tourism and intermittent mining activity. The population of Indian Springs is largely supported by the Creech Air Force Base.

Aside from changes in population resulting from variances in primary supporting industries, the populations of rural communities near the NTS may also respond to changes in activities at the NTS and surrounding land.

\subsubsection{Use of Adjacent Lands}

Ranching and mining remain important land uses in southern Nevada. More recently, recreational activities and irrigation-based agriculture have become important land uses in southern Nevada. Provided that the NTS remains withdrawn from all forms of appropriation, these activities likely will not have a significant impact on the NTS. The NTS is bounded on the north, east, and west by the NTTR. The use of the land and air space is controlled by the U.S. Air Force. These ranges, particularly to the north and east, provide a buffer zone between the NTS and public lands. Lands to the south and west of the NTS are administered by the BLM and NPS (Figure 2.2). This federal use and management of the land further buffer the NTS from external influence.

\subsubsection{Meteorology and Climatology}

Meteorology and climatology specific to the Area 3 RWMS is presented in detail in the PA and the Area 3 RWMS Characterization Report (Shott et al., 2000; NSTec, 2007b) and the annual Waste Management Monitoring Report (NSTec, 2007c). 


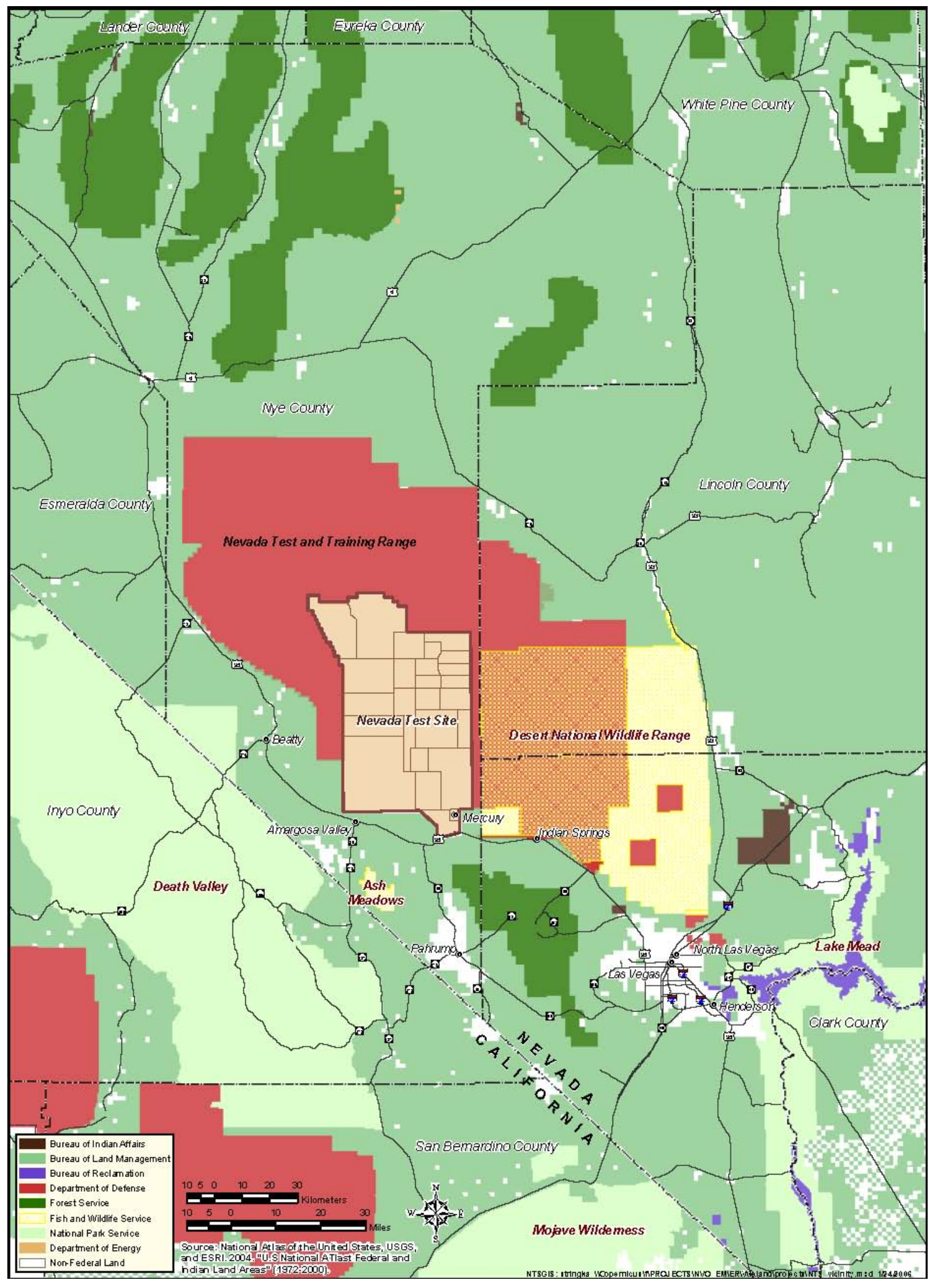

Figure 2.2 Federal Land Management Areas 


\subsubsection{Precipitation}

The NTS is between the northern boundary of the Mojave Desert and the southern limits of the Great Basin Desert. This “Transitional Desert” is considered to be typical of either the Dry Midlatitude or Dry Subtropical climatic zones. The climate is characterized by low precipitation, a large diurnal temperature range, a large evaporation rate, and moderate to strong winds.

Most precipitation in the Transitional Desert occurs in winter and summer. Winter precipitation is generally associated with transitory low-pressure systems originating from the west and occurring as uniform storms over large areas. Summer precipitation is generally associated with convective storms originating from the south or southwest and occurring as intense local storms.

The average annual precipitation based on a 45-year record (1961 to 2006) at a location $4.5 \mathrm{~km}$ (2.8 mi) northwest of the Area 3 RWMS is 164.1 millimeter (mm) (6.46 inches [in.]) (NSTec, 2007b). The average annual precipitation based on the 11-year record (1996 to 2006) collected at the Area 3 RWMS is $160.1 \mathrm{~mm}$ (6.30 in.) (NSTec, 2007c).

\subsubsection{Temperature}

Average daily temperatures at the NTS range between 2 degrees Celsius $\left({ }^{\circ} \mathrm{C}\right)$ (35 degrees Fahrenheit $\left.\left[{ }^{\circ} \mathrm{F}\right]\right)$ in January to $24^{\circ} \mathrm{C}\left(75^{\circ} \mathrm{F}\right)$ in August. Large daily fluctuations are common on the valley floors.

Daily air temperatures can vary from $-18{ }^{\circ} \mathrm{C}\left(0{ }^{\circ} \mathrm{F}\right)$ to $24^{\circ} \mathrm{C}\left(75^{\circ} \mathrm{F}\right)$ in winter and from $16^{\circ} \mathrm{C}$ $\left(60^{\circ} \mathrm{F}\right)$ to $42^{\circ} \mathrm{C}\left(108^{\circ} \mathrm{F}\right)$ in summer. During 2006 , the temperature range was $-13.7^{\circ} \mathrm{C}\left(7.34^{\circ} \mathrm{F}\right)$ to $40.0^{\circ} \mathrm{C}\left(104^{\circ} \mathrm{F}\right)(\mathrm{NSTec}, 2007 \mathrm{c})$.

\subsubsection{Potential Evapotranspiration}

Potential evapotranspiration (PET) at the NTS is high because of the large incident solar radiation and wind. PET at the Area 3 RWMS, calculated using local meteorology data, is approximately ten times the annual average precipitation (NSTec, 2007c).

\subsubsection{Wind}

Winds are primarily southerly during the summer months and northerly during the winter months. Wind speeds tend to be greater in the spring than in the fall. During 2006, the average wind speed at the Area 3 RWMS was 3.0 meters per second $(\mathrm{m} / \mathrm{s})(6.7$ miles per hour $[\mathrm{mph}])$ and the maximum gust was $17.9 \mathrm{~m} / \mathrm{s}$ (40.0 mph) (NSTec, 2007c). 


\subsubsection{Ecology}

Descriptions of plant and animal species and communities near the Area 3 RWMS are presented in the PA (Shott et al., 2000). Additional detailed discussions of NTS ecology are presented in Wills and Ostler (2001). A discussion of vegetation, noting depths and population, is detailed in Hanson and Ostler (2003).

\subsubsection{Vegetation}

The Transitional Desert includes vegetation associations of both the Mojave Desert and the Great Basin Desert. Communities of the Mojave Desert occur over the southern third of the NTS, on bajadas and mountain ranges at elevations below about 1,200 $\mathrm{m}(4,000 \mathrm{ft})$. They are limited to areas with mean annual minimum temperatures greater than $-2^{\circ} \mathrm{C}\left(28^{\circ} \mathrm{F}\right)$ and mean annual precipitation less than $18.3 \mathrm{~cm}$ (7.2 in.) (O’Farrell and Emery, 1976). Mojave Desert communities can have highly variable floristic compositions, but all are dominated by creosote bush and variable co-dominant shrubs. Shrub coverage varies from 7 to 23 percent for Mojave Desert communities on the NTS (Beatley, 1976).

Plant communities in Yucca Flat are dominantly Transitional Desert communities, although a few Mojave Desert assemblages are present. Plant communities near the Area 3 RWMS are similar to the desertthorn-hopsage or saltbush-winterfat assemblages (Winkel et al., 1995) and include desertthorn, Mormon tea, winterfat, fourwing saltbush, and littleleaf horsebrush (Hunter, 1992 [unpublished]; Winkel et al., 1995; Ostler et al., 2000).

Additional discussion on NTS vegetation can be found in Wills and Ostler (2001) and Hanson and Ostler, (2003).

\subsubsection{Plant Rooting}

Rooting depths of Mojave Desert or Transitional Desert plants at the NTS are concentrated near the surface, likely an adaptation to maximize capture of infiltration (Winkel et al., 1995; Hansen and Ostler, 2003). Wallace and Romney (1972) described root systems of several plants excavated from a wash in Rock Valley on the NTS. Creosote bush roots reached $168 \mathrm{~cm}$ (66 in.) below surface, desertthorn roots reached $122 \mathrm{~cm}$ (48 in.) below surface, Mormon tea roots reached $91 \mathrm{~cm}$ (36 in.) below surface, and winterfat roots reached $64 \mathrm{~cm}$ (25 in.) below surface. Over 82 percent of the creosote roots were found in the top $20 \mathrm{~cm}$ (98 in.) of soil.

Wallace et al. (1980) excavated root systems of several Mojave Desert species at the NTS. The roots were distributed in the top $51 \mathrm{~cm}$ (20 in.), except for fourwing saltbush and shadscale; less than 2 percent of the roots of these two species were found below $51 \mathrm{~cm}(20 \mathrm{in}$.). Wirth et al. (1999) compiled rooting depths of various plant species found on the NTS. The depth of rooting is closely tied to soil characteristics, a relationship that can be applied advantageously to the design of closure covers. 
Hanson and Ostler (2003) found sparse plant communities in three study plots near the Area 3 RWMS. Total percent shrub cover at the plots varied from 3.4 to 36.9 percent. Maximum root depth for the species with the highest relative densities and highest relative abundances were less than $60 \mathrm{~cm}(2 \mathrm{ft})$. Creosote bush had the deepest roots, with a maximum observed root depth of $180 \mathrm{~cm}$ (5.9 ft); however, creosote was found at only one plot, with a relative density of 3 percent and a relative abundance of 2 percent. Consequently, the roots of native shrubs likely to revegetate the covers of the Area 3 RWMS are unlikely to penetrate the covers (NSTec, 2007b).

\subsubsection{Animal Burrowing}

Ants and termites are the most numerous burrowing insects on the NTS (O'Farrell and Emery, 1976). Rodents are the most common of the mammalian species on the NTS (Allred et al., 1963). The depth of burrowing is closely tied to soil conditions and plant rooting depths. Most animals at the NTS confine burrowing activities to the upper $3 \mathrm{~m}(10 \mathrm{ft})$ of soil. Typical burrowing depths for the rodents commonly observed at the NTS are less than $1 \mathrm{~m}$ (39 in.). Kit fox burrows have been found as deep as $3 \mathrm{~m}(10 \mathrm{ft})$ at the NTS, but they have a low population density; therefore, the potential for disturbance of waste by a kit fox burrowing through the

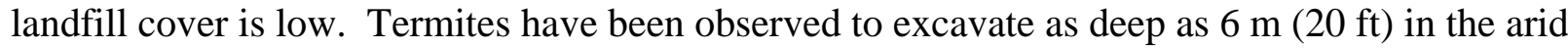
southwest; however, because roots are a primary food source, their burrowing depths are closely related to rooting depths. Shrubs with shallow rooting depths predominate in the vicinity of the Area 3 RWMS. Some ant species may bury deeper than termites, but the overall volume of material likely to be removed to the surface by these insects is small (NSTec, 2007b).

\subsubsection{Geology}

\subsubsection{Regional and Site-Specific Geology/Topography}

Detailed descriptions of the geology of Yucca Flat are in the Area 3 RWMS PA/CA report (Shott et al., 2000).

\subsection{Regional Geology}

A sequence of rocks at the NTS is composed of Proterozoic and Paleozoic (primarily marine, sedimentary and metasedimentary rocks), locally intrusive Cretaceous granitic rocks, Miocene volcanic rocks, and post-volcanic sand and gravel. This sequence would be approximately $10,500 \mathrm{~m}(35,000 \mathrm{ft})$ thick if stacked at one location according to age (Frizzell and Shulters, 1990). The geometry of these rocks is complex. The Proterozoic and Paleozoic rocks were significantly deformed in Late Mesozoic time (approximately 70 million years ago) during two phases of thrust faulting. The regionally distributed Belted Range thrust displaced easterly Late Proterozoic sedimentary rocks on Mississippian rocks; the younger and more locally distributed $\mathrm{CP}$ thrust resulted in westward thrusting and locally intense folding of the mostly Paleozoic stratigraphic section (Cole and Cashman, 1999). In mid-Tertiary (Miocene) to Quaternary time, the Proterozoic and Paleozoic rocks and the overlying Miocene volcanic rocks were deformed by large-scale extensional block faulting, which is largely responsible for the present Basin and 
Range topography in Nevada. The extensional faulting is thought to have occurred in two phases across the NTS. The initial phase, about 14 to 16 million years ago, consisted of high-angle northwest- and northeast-trending normal faults, and detachment faults (Cole et al., 1989). A second phase, younger than 11 million years ago, consisted of steeply dipping north-to-southtrending normal faults. This later phase is responsible for the basin-forming faults presently obvious in Yucca Flat (Dockery-Ander, 1984).

\subsection{Yucca Flat Geology}

The geologic structure of Yucca Flat is typical of intermontane basins throughout the Basin and Range Province of Nevada and adjoining states. The surrounding mountain ranges consist primarily of Tertiary volcanic rocks and underlying Paleozoic sedimentary and metasedimentary rocks (Figure 2.3). These ranges bound rotated and downdropped blocks in the basin. Erosion of the mountain ranges has resulted in deposition of a significant thickness of alluvium in the basin. The topography of the prealluvial surface and continuing tectonic activity during deposition of the alluvium influence the present thickness of the alluvium. The thickness of alluvium in southern Yucca Flat ranges between 30 to over $914 \mathrm{~m}$ (98 to over 3,000 ft) (Drellack, 1994). At the Area 3 RWMS, alluvium is approximately $300 \mathrm{~m}$ (984 ft) thick. Extensive stratigraphic data have been collected from boreholes in Yucca Flat (Drellack and Thompson, 1990; Gonzales et al., 1998). Borehole U-3cn\#5 is the closest of the deep boreholes drilled in Yucca Flat to the Area 3 RWMS. The stratigraphy of this borehole is approximately $279 \mathrm{~m}(915 \mathrm{ft})$ of alluvium, underlain by $567 \mathrm{~m}$ (1,860 ft) of various tuffs (846 m [2,775 ft] deep), underlain by carbonate rocks. The borehole extended $63 \mathrm{~m}(207 \mathrm{ft})$ into the carbonate rocks, reaching a total depth of $909 \mathrm{~m}(2,982 \mathrm{ft})$.

Principal faults in Yucca Flat are the Yucca Fault and the Carpetbag Fault (Figure 2.3). Both faults are east-dipping, moderately high-angle normal faults. The Yucca Fault trends north-south through the east-central part of the valley. The Carpetbag Fault trends north-south through the western part of the valley. Toward the south, the Carpetbag Fault steps eastward where it is called the Topgallant Fault. Knauss (1981) brackets the last natural movement along the Carpetbag fault between 37,000 and 93,000 years ago, and along the Yucca Fault at less than 35,000 years ago. Apparent surface movement on the faults may be due to localized differential compaction of the alluvium related to recent underground nuclear testing rather than tectonic movement along the entire fault plane.

The Area 3 RWMS is on a structural block bounded on the west by the Yucca Fault and on the east by a west-dipping fault known as the Area 3 Fault (Figure 2.3). The Area 3 Fault is a wishbone-shaped fault system in Area 3 and southern Area 7. The nuclear-testing-induced fractures, which delineated most of the west branch of the Area 3 Fault, are no longer evident. 


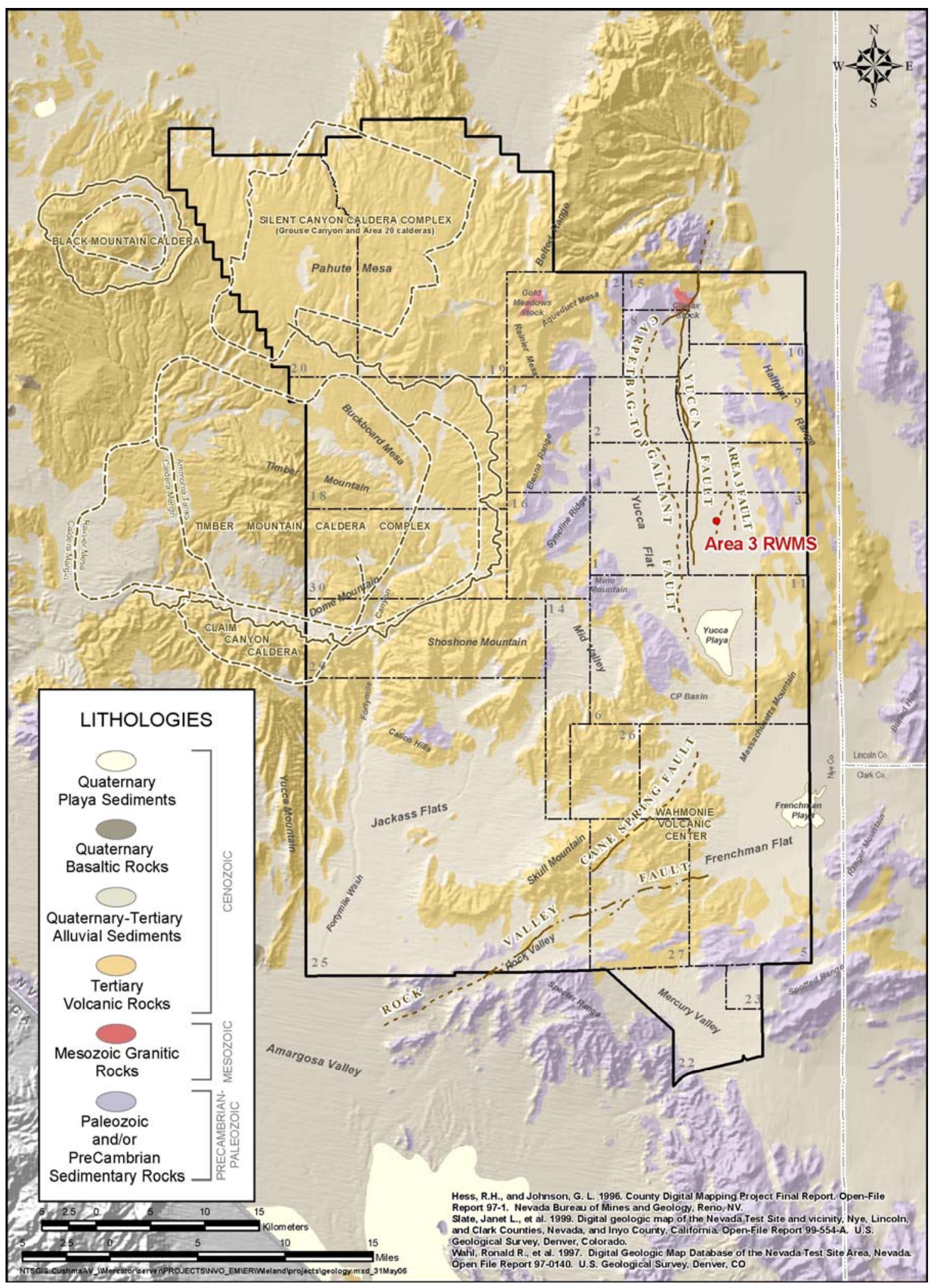

Figure 2.3 Simplified Geologic Map 
The mapped trace of the west branch of the Area 3 Fault crosses the eastern side of the Area 3 RWMS. Continuity of beds exposed in a trench dug across the trace of the fault within the RWMS shows no major vertical displacement since as a minimum early Holocene time (7,000 to 10,000 years), and probably since the Middle Pleistocene (several hundreds of thousands of years). Minor vertical fractures with minimal extent are present. The lack of major displacement within this time frame suggests that disposal operations and closure covers will not be impacted by the Area 3 Fault within the foreseeable future (BN, 1998a).

\subsubsection{Seismology}

The U.S. geological Survey (USGS) maintains seismic monitoring stations on and near the NTS. Records at the USGS Earthquake Hazards Program and Nevada Seismological Laboratory indicate low-magnitude earthquakes are common at the NTS.

The predicted maximum magnitude earthquake (and the associated peak acceleration) has a return period between 12,700 and 15,000 years (Metcalf, 1983). The seismic studies show a 0.54 probability of an earthquake with a Richter magnitude greater than 6.8 within the next 10,000 years.

Seismic hazard studies conducted at the NTS (Campbell, 1980; Battis, 1978; Rogers et al., 1977; and Hannon and McKague, 1975) agree that the predicted maximum Richter magnitude for an earthquake is between 5.8 and 7.0, with a peak acceleration between 0.7 and $0.9 \mathrm{~g}$ (where $\mathrm{g}$ is standard acceleration of gravity, $9.80665 \mathrm{~m} / \mathrm{s}^{2}$ ).

Later studies predict less ground movement. Wong et al. 1997 reported a preliminary probabilistic seismic hazard analysis of ground shaking for the Yucca Mountain area considered 88 Quaternary faults within $100 \mathrm{~km}$ (62.14 mi)and characterized them for probability of being seismogenic, recurrence, slip rate, and other factors. Regionally, fault slip rates range from 0.00001 to 4 millimeters per year (mm/yr). Most of the known Quaternary faults near Yucca Mountain have slip rates on the order of 0.001 to $0.001 \mathrm{~mm} / \mathrm{yr}\left(3.9 \times 10^{-5}\right.$ in. to $3.0 \times 10^{-5} \mathrm{in}$.). Because of low slip rates of Basin and Range faults, the dominant contributor to the groundshaking hazard was found to be background earthquakes not associated with the modeled local faults. Only a few regional faults contribute to the ground-shaking hazard at return periods of less than 100,000 years. A new attenuation relation developed specifically for earthquakes in extensional tectonic regimes gives lower peak accelerations in rock than five predominantly California-based relations used in analyses. Peak horizontal rock accelerations are $0.21 \mathrm{~g}$ and $0.50 \mathrm{~g}$ for return periods of 1,000 and 10,000 years respectively (Wong et al., 1996). This is significantly lower than rates derived in earlier studies. Unconsolidated alluvium can attenuate ground shaking further.

USGS has performed detailed studies of faults near Yucca Mountain, which provided fundamental data for evaluating earthquake risk for the NTS region (Keefer et al., 2004).

Subject Matter Experts (SMEs) continue to study probabilistic seismic hazards in the Yucca Mountain region; however, the results of further analysis are not likely to affect cover design 
decisions for the Area 3 RWMS. Because of the absence of layers that could be disrupted by movement, the monolayer-ET design for closure covers intrinsically is not prone to significant damage from earthquakes.

\subsubsection{Volcanism}

The risk of volcanism in the NTS region includes the potential for either future silicic or basaltic volcanism. Silicic volcanism is characterized by large-volume, explosive eruptions associated with large caldera complexes; whereas post-Miocene basaltic volcanism is characterized by small volume eruptions $\left(<3 \mathrm{~km}^{2}\right)$ that produce local clusters of individual scoria cones and associated lava flows of limited extent. The hazard for silicic volcanism is considered to be negligible because:

- Since its peak (from 9 to 15 million years ago), there has been a significant decrease and, in most areas, a cessation of silicic volcanism within the central and southern parts of the Great Basin. The last major silicic events were the Black Mountain caldera, which erupted 9.4 million years ago, and the Stonewall Mountain caldera, which erupted 7.6 million years ago.

- Silicic volcanism has been absent in the NTS region for the past 7.6 million years.

- Quaternary (less than 10,000 years) silicic volcanism is restricted to the eastern and western margins of the Great Basin (Crowe et al., 1983). A transition from predominantly silicic volcanism to basaltic volcanism occurred approximately 10 million years ago.

Late- and post-Miocene basaltic volcanism in the NTS region is divided into two episodes: largevolume basaltic centers that are spatially and temporally associated with the waning phase of silicic volcanism and small-volume, spatially scattered basalt centers that postdate silicic volcanism (Crowe, 1990). The latter episode of volcanism is subdivided into two cycles: late Miocene basalt centers in the east and north-center of the NTS, and Pliocene and Quaternary basalt centers primarily in the southwest part of the NTS region. The youngest basaltic volcanic center in the NTS region is the 80,000-year-old basalt of Lathrop Wells. The youngest basalt found within Yucca Flat, at 8.4 million years, is between 226 and $308 \mathrm{~m}$ (740 and 1,010 ft) deep in borehole UE-1h, $1.6 \mathrm{~km}$ (1 mi) southwest of the Area 3 RWMS. The youngest basalt within Frenchman Flat, at 7.3 million years, includes three north-east aligned basalt volcanoes exposed at the surface in Nye Canyon, approximately $21 \mathrm{~km}(13 \mathrm{mi})$ northeast of the Area 5 RWMS.

The greatest hazard of future basaltic volcanism in the NTS region is within zones of Pliocene and Quaternary volcanism (Crowe et al., 1998a). The Area 3 and Area 5 RWMSs are outside and a considerable distance from all Pliocene and Quaternary volcanic zones. Based on studies at Yucca Mountain, Crowe et al. (1998a) calculated the probability of magmatic disruption of an equivalent area outside a volcanic zone to be 3E-09 or 3E-06 over a 1,000-year compliance period. This probability is sufficiently low that basaltic volcanism can be dismissed as a credible event for the RWMSs. 


\subsubsection{Hydrology}

\subsubsection{Surface Water}

No permanent surface water is present within Yucca Flat, with the exceptions of small artificial impoundments and five springs that issue from perched aquifers recharged from local infiltration through fractures in the surrounding mountains. Most water that issues from these springs travels only a short distance before evaporating or infiltrating into the ground. Reitman Seep, located $6.4 \mathrm{~km}$ (4 mi) northeast of the Area $3 \mathrm{RWMS}$, is the closest spring to the site.

Alluvial fans within Yucca Flat are cut by numerous arroyos (dry washes) that drain storm runoff to the playa. Water that accumulates on the playa typically evaporates or infiltrates, or both, within days to several weeks but sometimes persists more than one month. Yucca Playa is approximately $8 \mathrm{~km}$ (5 mi) south of the Area 3 RWMS.

A flood hazard assessment for the Area 3 RWMS considered the entire watershed of Yucca Flat, but focused on a $94 \mathrm{~km}^{2}\left(36 \mathrm{mi}^{2}\right)$ drainage area east of the Area 3 RWMS that has the greatest potential to impact the site. The assessment determined that the Area 3 RWMS is not within a Federal Emergency Management Agency designated 100-year, 6-hour flood hazard zone (Miller, 1996).

\subsubsection{Groundwater}

\subsection{Unsaturated Zone}

Climate and vegetation strongly control the movement of water in the upper $2 \mathrm{~m}(7 \mathrm{ft})$ of the alluvium. The magnitude and direction of both liquid and vapor fluxes vary seasonally and often daily. Except for periods following precipitation events, water contents in this near-surface region are low. Below the near-surface region is a region where relatively steady upward movement of water is occurring. In this region of slow upward water movement, stable isotope compositions of soil pore water show that evaporation is the dominant process (Tyler et al., 1996). This region extends to depths from approximately 3 to $49 \mathrm{~m}$ (10 to $160 \mathrm{ft}$ ) in Area 3. Below this region, water potential measurements indicate the existence of a static region that begins between approximately 49 to $119 \mathrm{~m}$ (161 and $390 \mathrm{ft}$ ) in Area 3 (Shott et al., 2000). In this static region, essentially no vertical liquid flow is currently occurring. Below this static region, flow is steady and downward due to gravity. Deep drainage and potential groundwater recharge appear to be occurring primarily along mountain fronts but also in isolated valley locations at the NTS where soil permeabilities are high and vegetation is sparse.

Stable isotope compositions of pore water indicate that infiltration into the static region must have occurred under cooler, past climate conditions (Tyler et al., 1996). If contaminants were to migrate below the currently static region, movement to the groundwater would be extremely slow due to the low water content of the alluvium. Conservative estimates of travel times from 
just beneath the root zone to groundwater in Area 3 are in excess of 500,000 years, assuming zero upward flux (Levitt et al., 1998).

Based on the results of extensive research, field studies, modeling and monitoring data, which are summarized in the Area 3 RWMS PA (Shott et al., 2000) and in Levitt et al. (1998), there is no areally distributed groundwater recharge under current climatic conditions at the RWMSs. Recent studies indicate that under bare-soil conditions, such as those found at the operational waste unit covers, some drainage may occur through the covers into the waste zone. This drainage is estimated to be about 8 percent of the annual rainfall at Area 5 and 10 percent of annual rainfall at Area 3, based on conservative modeling results (Desotell et al., 2006; Levitt et al., 1999). Drainage through the bare waste covers should not be confused with groundwater recharge because the covers will ultimately become partially vegetated, eliminating the downward pathway.

\subsection{Saturated Zone}

The NTS is located within the Death Valley Regional Flow System (DVRFS), one of the major hydrologic subdivisions of the southern Great Basin (Belcher, 2004). The DVRFS covers an area of about $40,920 \mathrm{~km}^{2}\left(15,800 \mathrm{mi}^{2}\right)$. This regional flow system consists primarily of volcanic rock in the west and carbonate rock in the east and is estimated to transmit more than 86 million cubic meters $\left(\mathrm{m}^{3}\right)$ (70,000 acre-feet) of groundwater annually. Most of this flow moves through a thick sequence of Paleozoic carbonate rock extending throughout the subsurface of central and southeastern Nevada and is sometimes referred to as the "central carbonate corridor." The division of the DVRFS into different groundwater flow systems within the NTS is based on the concept of a groundwater subbasin, defined as the area that contributes water to a major surface discharge. Three principal groundwater subbasins have been identified within the NTS region as the Ash Meadows, Oasis Valley, and Alkali Flat-Furnace Creek Ranch subbasins (Figure 2.4). Yucca Flat and Frenchman Flat lie within the Ash Meadows Subbasin (Laczniak et al., 1996).

The Ash Meadows subbasin covers an area of about 10,360 $\mathrm{km}^{2}\left(4,000 \mathrm{mi}^{2}\right)$. Precipitation is believed to recharge the subbasin along its northern boundary at the Belted, Reveille, Timpahute, and Pahranagat Ranges, along its eastern boundary at the Sheep Range, and along its southern boundary at the Spring Mountains. Recharge is also suspected to occur within the subbasin at higher elevations of the Spotted, Pintwater, and Desert Ranges. Groundwater primarily flows through the lower carbonate-rock aquifer and discharges along a line of springs in Ash Meadows. Groundwater flow rates through the different lithologic units of the Ash Meadows subbasin are highly variable. Estimates range from less than 0.3 to more than $300 \mathrm{~m} /$ day (1 to $1000 \mathrm{ft} /$ day), depending on the unit. In general, the regional carbonate-rock aquifer is believed to transmit water at the fastest rate, whereas the basement and Eleana confining units transmit water at the slowest rate, and volcanic and valley-fill aquifers and confining units transmit water at intermediate rates (Laczniak et al., 1996).

The lower carbonate-rock aquifer within the Ash Meadows subbasin is the only subsurface pathway by which groundwater leaves Yucca Flat and Frenchman Flat basins. Groundwater flows south from Yucca Flat into Frenchman Flat and then southwest toward downgradient areas (primarily Ash Meadows). Water levels within the lower carbonate-rock aquifer indicate that the 
gradient is nearly flat (less than $0.3 \mathrm{~m} / \mathrm{km}$ [1.6 ft/mi]) between Yucca Flat and Frenchman Flat and down to the discharge area at Ash Meadows. This flat gradient is an indication of a high degree of hydraulic continuity within the aquifer that is probably a result of a high fracture (secondary) permeability (Laczniak et al., 1996).

Recent work for the UGTA project has enhanced the understanding of the hydrology of the NTS through the definition of hydrogeologic and hydrostratigraphic units (HGUs and HSUs) for use in modeling the geology and hydrology of the NTS area (Gonzales et al., 1998). Many of these units are applicable to the Yucca basin, as described below.

All the rocks of the Yucca Flat study area can be classified as one of eight HGUs, which include the alluvial aquifer (AA), four volcanic HGUs, one intrusive unit, and two HGUs that represent the pre-Tertiary rocks.

The strata in the Yucca Flat area have been subdivided into eleven Tertiary-age HSUs (including the Tertiary/Quaternary alluvium), one Mesozoic intrusive HSU, and six Paleozoic HSUs. The dominant HSUs in the former Yucca Flat testing area, in descending order, are the AA, the volcanic aquifers (including the Timber Mountain and Topopah Spring welded tuff aquifers [TM-WTA and TSA]), the lower tuff confining unit (LTCU), the regional carbonate aquifer (or lower carbonate aquifer [LCA]), and the lower clastic confining unit (LCCU). The area immediately north of Yucca Flat proper includes several additional welded tuff and lava flow aquifers (e.g., Tub Spring and Grouse Canyon welded tuff aquifers), and the Mesozoic granite intrusive confining unit. More information regarding HSUs in Yucca Flat can be found in Gonzales et al. (1998).

The static water level (SWL) in the Yucca Flat basin is relatively deep, ranging in depth from about $183 \mathrm{~m}$ (600 ft) in extreme western Yucca Flat to more than $580 \mathrm{~m}(1,900 \mathrm{ft})$ in northcentral Yucca Flat. The elevation of the water table in the Yucca Flat area varies from 1,340 m

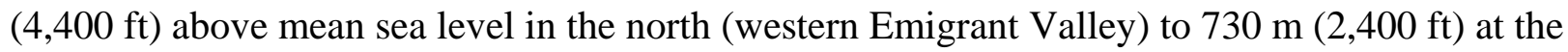
southern end of Yucca Flat (Laczniak et al., 1996; Hale et al., 1995). Throughout much of the Yucca Flat area, the SWL typically is located within the lower portion of the volcanic section, in the Yucca Flat lower confining unit. Beneath the hills surrounding Yucca Flat, the SWL can be within the Paleozoic units, whereas in the deeper structural subbasins of Yucca Flat, the Timber Mountain Tuff, and the lower portion of the alluvium are also saturated. 

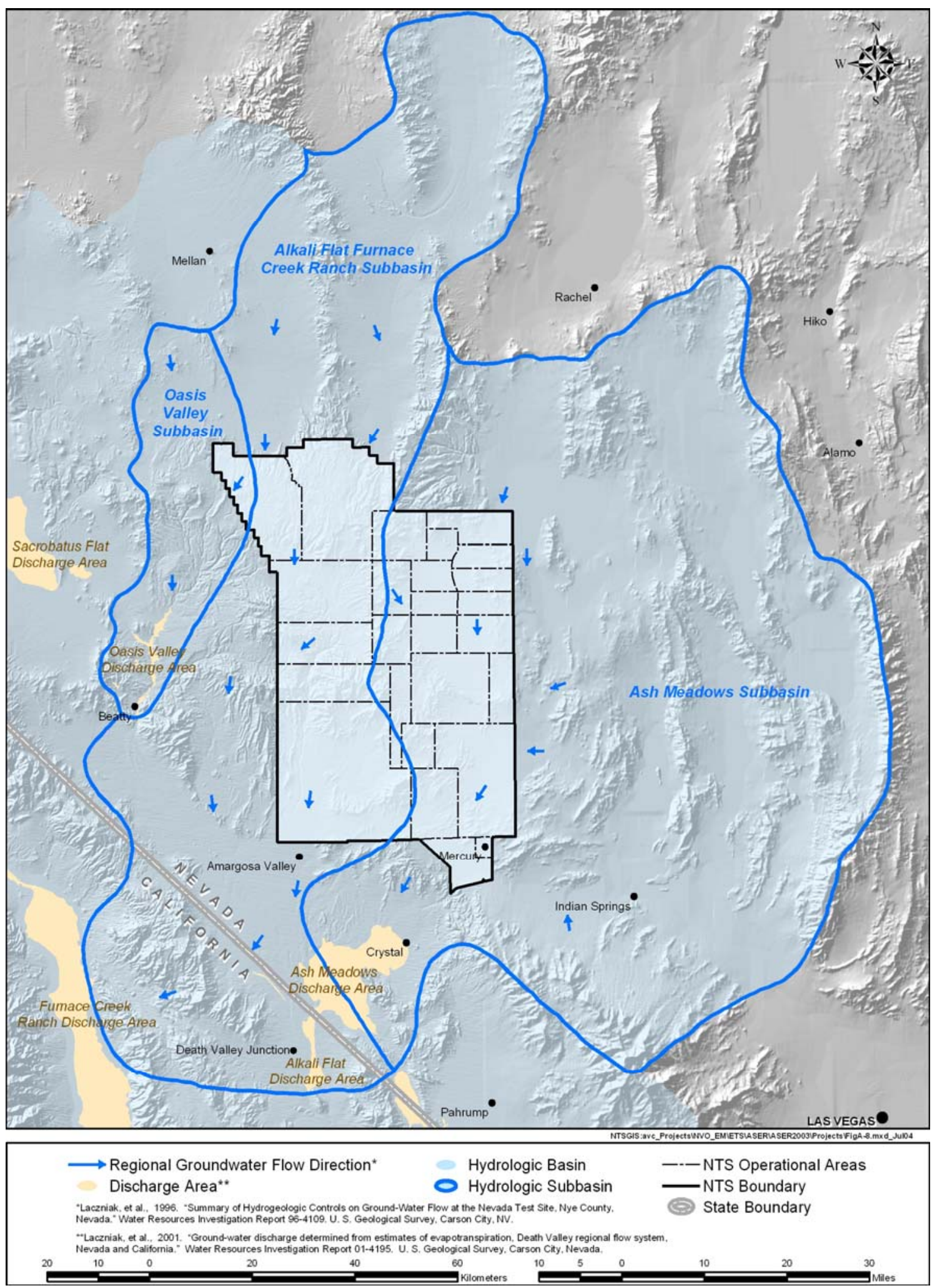

Figure 2.4 Hydrologic Subbasins 
Fluid levels measured in wells completed in the alluvial aquifer and volcanic units in the eastern two-thirds of Yucca Flat are typically about $20 \mathrm{~m}$ (70 ft) higher than in wells completed in the regional carbonate aquifer (Winograd and Thordarson, 1975; IT, 1996a,b). The hydrogeology of these units suggests that the higher elevation of the water table in the overlying Tertiary rocks is related to the presence of low-permeability zeolitized tuffs of the tuff confining unit (aquitard) between the Paleozoic and Tertiary aquifers. Detailed water-level data indicate the existence of a groundwater trough along the axis of the valley. The "semi-perched" water within the AA and volcanic aquifers eventually moves downward to the carbonate aquifer in the central portion of the valley. Water-level elevations in western Yucca Flat are also well above the regional water level. The hydrology of western Yucca Flat is influenced by the presence of the Mississippian siliciclastic rocks, which directly underlie the carbonate aquifer of the upper plate of the CP thrust (locally present), AA, and volcanic rocks west of the Topgallant fault. This geometry is a contributing factor in the development of higher (semi-perched) water levels in this area. The Climax stock also bears perched water (Walker, 1962; Laczniak et al., 1996) well above the regional water level.

The present structural interpretation for Yucca Flat depicts the pre-Cambrian siliciclastic sedimentary rocks (also referred to as the LCCU) at great depth, except in the northeast corner of the area. The Zabriskie Quartzite and Wood Canyon Formation, which are both classified as clastic confining units, are exposed in the northern portion of the Halfpint Range. The high structural position of the LCCU there (and in combination with the Climax stock) may be responsible for the steep hydrologic gradient observed between western Emigrant Valley and Yucca Flat. Water-level data for the LCA in the southern part of the NTS are limited, but indicate a fairly low gradient in the Yucca Flat, Frenchman Flat, and Jackass Flats areas. This gentle gradient implies a high degree of hydraulic continuity within the aquifer, presumably due to high fracture permeability (Laczniak et al., 1996). Furthermore, the similarity of the water levels measured in Paleozoic rocks (LCA) in Yucca Flat and Frenchman Flat implies that, at least for deep interbasin flow, there is no groundwater barrier between the two basins.

Based on the existing data as interpreted from a regional groundwater flow model (DOE, 1997), the overall groundwater flow direction in the Yucca Flat and Frenchman Flat areas is to the south. Groundwater ultimately discharges at Ash Meadows and Franklin Lake Playa to the south and Death Valley to the southwest.

\subsubsection{Geochemistry}

Three types of groundwater chemistry facies dominate the region: (1) a calcium-magnesium bicarbonate (Ca-Mg- $\mathrm{HCO}_{3}$ ) facies within the carbonate units, (2) a sodium and potassium bicarbonate (Na-K- $\mathrm{HCO}_{3}$ ) facies derived from groundwater in volcanic rocks, and (3) a mixed facies containing components from both (1) and (2). The Na-K-HCO facies (2) is found within the lava-flow aquifer and tuff-aquitard units. The facies also is seen in portions of the valley-fill aquifer, where a major portion of the alluvial-fill material has been derived from the erosion of volcanic units. The Ca-Mg-HCO 3 composition (1) is found within the Paleozoic carbonate units, such as the LCA and the valley-fill aquifers that are composed of carbonate detritus. Most of the calcium and magnesium present is from the dissolution of limestone and dolomite $\left(\mathrm{CaCO}_{3}\right.$ and 
CaMg $\left.\left[\mathrm{CO}_{3}\right]_{2}\right)$ mineralization in the unit as it conducts flow. Water of the mixed facies (3) contains portions of both the Na-K and Ca-Mg ions groups (Chapman, 1994; Winograd and Thordarson, 1975).

\subsubsection{Soil Geochemistry}

The geochemistry of the native alluvium affects the transport of radionuclides by affecting their solubility and sorption characteristics. The alluvium is dominated by quartz, feldspar, and cristobalite, with calcite, gypsum, and minor amounts of clays and zeolites. Measured $\mathrm{pH}$ values range between 7 and 9, indicating neutral to alkaline conditions (Cochran et al., 2001). The presence of clays and zeolites in an alkaline environment generally inhibit the mobility of radionuclides. The geochemical environment of the closure cover is anticipated to be largely determined by the geochemistry of the constituent alluvium.

\subsubsection{Natural Resources}

Exploration and exploitation of natural resources near the RWMSs potentially could have an impact on closure and monitoring over both the short- and long-terms. A natural resource is economically viable if it is available in sufficient quality and quantity and a demand for the resource exists. Four potentially viable resources are identified for the NTS: sand and gravel, minerals, hydrocarbons, and water.

The Area 3 RWMS is located on alluvial fans composed primarily of sand and gravel. Most sand and gravel is used for road base, building pads, and other fill structures. Construction of closure covers may require a relatively large volume of sand and gravel, presumably derived from within or near the RWMS. Exploitation of sand and gravel from near the RWMS for other than local use is unlikely because the gravels are composed largely of silicic volcanic rocks, which tend not to be durable. Additionally, good quality sand and gravel are generally available elsewhere.

Four mining districts are present on the NTS: Calico Hills, Oak Spring, Mine Mountain, and Wahmonie. Of these four districts, Calico Hills is considered to be sufficiently distant from Yucca Flat and Frenchman Flat to not impact the RWMS significantly if the district should be developed.

The Oak Spring district is in northern Yucca Flat, the Mine Mountain district is in southwestern Yucca Flat, and the Wahmonie district is in Jackass Flats. The Oak Spring district is considered to have moderate potential for tungsten, and silver may be present (SAIC/DRI, 1991). Although economic deposits of silver and gold were extracted from the Mine Mountain and Wahmonie districts, the current economic potential for these districts is uncertain (Richard-Haggard, 1983; Gustafson et al., 1993). Overall, especially considering that DOE anticipates institutional controls over the NTS for the foreseeable future, the probability of mineral exploration and exploitation that would impact the RWMS is low. 
The potential for oil and natural gas in southern Nye County is thought to be low (Garside et al., 1988; Castor et al., 1990). Trexler et al. (1996), however, suggest a "cautiously optimistic view of the hydrocarbon potential" for the NTS and surrounding area based on the occurrence of thrust plates that provide potential reservoir space and a favorable thermal history. Studies in southern Nye County and the NTS do not indicate the presence of coal, tar sand, or oil shale (Gustafson et al., 1993).

Groundwater under the NTS is generally acceptable for drinking water and industrial and agricultural uses (Chapman, 1994). Industrial and agricultural uses currently are precluded because of land use and institutional controls over the NTS into the foreseeable future. Human consumption of water has the greatest probability for impacting the RWMS. Such impact is likely not to occur in the near term because current demand is low, the cost of extracting water from below Yucca Flat and Frenchman Flat is high, and water is available from other sources.

\subsection{Facility Characteristics}

\subsubsection{Water Infiltration}

Measurement and modeling of water balance in test monolayer-ET covers at the Area 5 RWMS and at National Laboratories in arid regions of the United States show that the design will minimize infiltration of water (Desotell et al., 2006; Dwyer, 1998).

Water balance studies conducted at the Area 3 and Area 5 RWMSs have shown that a monolayer-ET closure cover is most effective when vegetated (Desotell et al., 2006; Desotell et al., 2007). Under current climatic conditions, any water that infiltrates into the soil is quickly extracted by evaporation and uptake by plant roots, even with a relatively low density of plant cover. Closure covers constructed over waste units will be planted with species native to the area. Shallow-rooted, invasive plant species will also be allowed to vegetate the closure covers. Over the long term, an established plant assemblage is expected to survive the ambient range of environmental conditions. Plants will also serve to maintain stability of the closure covers. The cover will have adequate slope to safely carry any precipitation runoff without significant erosion.

Because of the distances between waste disposal units at the Area 3 RWMS, each unit will have an independent, above-grade final closure cover. The final closure covers will incorporate any

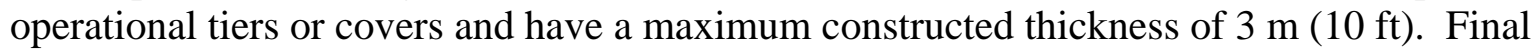
closure covers will be graded to provide drainage from the covers; areas between the units will be graded so that drainage will exit the site without impacting adjacent closed units. 


\subsubsection{Disposal Unit Cover Integrity}

Because performance objectives of the Area 3 RWMS PA can be met with only an operational closure cover, an approach for the final closure cover is taken for both closure and monitoring that emphasizes simplicity of design and maintenance.

The operational closure cover is native soil placed over disposed waste containers to provide temporary protection to the containers and containment of the contents. Operational closure covers are designed to have equivalent performance to standard closure covers. At the Area 3

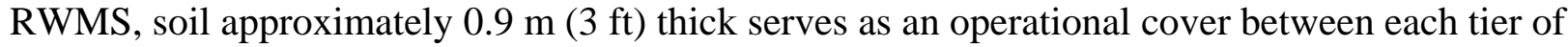
waste.

The basic closure cover design for the disposal units is of the vegetated monolayer-ET type. Figure 2.5 is the conceptual hydrologic model of cover performance. Liquid advection stops at the no liquid flow boundary (NLFB). A vegetated monolayer-ET closure cover was deployed in FY 2000 at the Central Nevada Test Area north of the NTS, and early in FY 2001 on U-3ax/bl at the Area 3 RWMS (DOE, 2000a). An instrumented weighing lysimeter facility near the Area 5 RWMS and a drainage lysimeter facility constructed in 2001 at the Area 3 RWMS have been collecting characterization data for optimization of the design of the closure covers at the NTS.

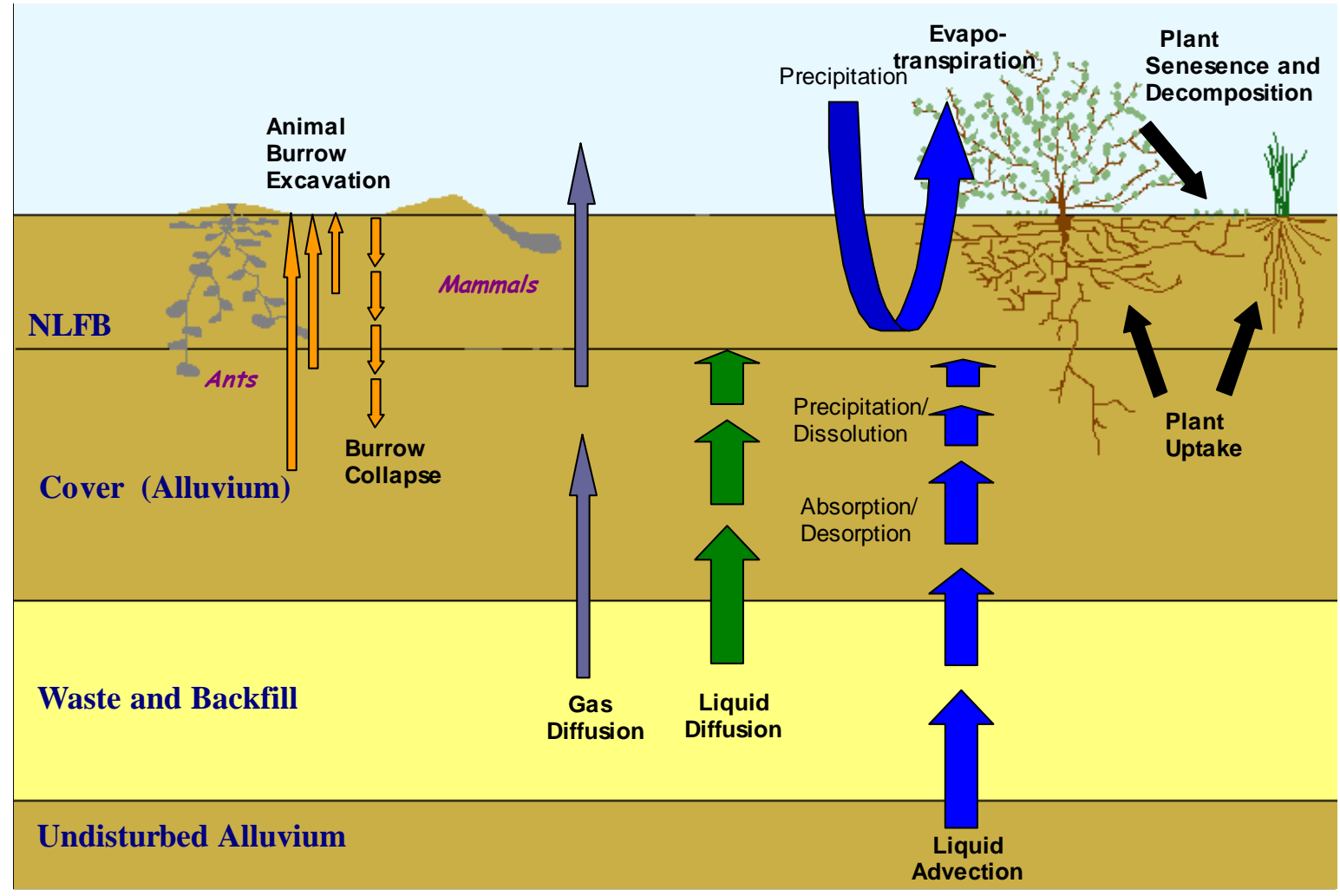

Figure 2.5 Conceptual Model of Flow and Transport 
A monolayer-ET closure cover was selected as the preferred alternative design to a multilayered landfill closure cover and other alternative designs only after a comprehensive evaluation of many alternatives. Evaluation of alternative designs included review of relevant literature, research on water balance in vegetated and unvegetated weighing lysimeters in Area 5 of the NTS; hydrogeologic modeling, site visits to closure cover test facilities at Sandia National Laboratories (SNL) and Los Alamos National Laboratory (LANL), NNSA/NSO-sponsored workshops, and a conference on vadose zone monitoring. The various forums included representatives from industry, academia, and government, including SNL and LANL, and provided the opportunity to discuss closure and monitoring of waste-disposal units. Multiple lines of evidence suggest that a monolayer-ET design in an arid environment will perform according to performance criteria over long periods of time even under conditions of subsidence and will meet the regulatory standards and performance objectives. The monolayer-ET cover and natural conditions at the NTS will integrate and operate as a system.

Natural conditions that optimize the system are extremely low precipitation and high potential evapotranspiration rates, great depth to groundwater, and negligible recharge to groundwater.

The operational and final closure covers will be constructed of native soil. Vegetation plays an important role in cover stability and functionality by stabilizing cover soil to reduce erosion by wind and water. Cover functionality is improved when moisture is drawn out of the cover by roots and transpired to the atmosphere.

Cover vegetation will be selected to include native plant species with shallow rooting depths. Studies by Wirth et al. (1999) and Hansen and Ostler (2003) identified several native species whose rooting depths were less than $51 \mathrm{~cm}$ (20 in.). This depth provides a good balance between cover stability and impact to the waste unit because the rooting depth is a fraction of the total cover thickness.

Seeding will be conducted using a sprayer and a hose with an adjustable nozzle; any planting will be conducted manually. The seeds or plantings are typically covered with straw and irrigated as necessary to ensure successful root development. The vegetation is generally planted on the closure cover in the winter to reduce irrigation requirements.

\subsubsection{Structural Stability}

Design of any closure cover must consider the potential for plant root intrusion into disposed waste that could provide a pathway for the release of radionuclides. Cover designs also must consider the potential for animals burrowing into the closure cover or, less likely, into disposed waste. Burrowing by animals could degrade cover integrity, alter hydraulic properties of the cover, or transport radionuclides to the accessible environment (Hankonson et al., 1992). Mobile fauna could disperse contamination to distant sites, and animals could introduce contamination into trophic pathways, eventually leading to humans that consume wild game (O'Farrell and Gilbert, 1975). Design alternatives to mitigate these conditions will be included in closure plans specific to individual disposal units or groups of units. 
As shown in the Area 3 RWMS PA, the potential for significant flora and fauna intrusion through the closure cover to waste burial depths is low, and, consequently, the amount of contaminants that plants and animals could move to the ground surface and the atmosphere is low. Plants and animals do not appear to be a significant risk in maintaining the containment structure.

Structural stability of the closure cover would be affected by differential subsidence that would occur intermittently following infilling of void space around containers and degradation and collapse of disposed waste containers. Parameter values affecting subsidence (such as void space volume), as well as subsidence estimates, are described in Shott et al. (2000), Barker (1997), and Obi et al. (1996). During a period of active institutional control, any subsidence that might occur would be mitigated immediately by filling and grading the subsided areas with native soil, thus ensuring structural stability of the cover at all times. Any major damage to vegetation on the closure covers from maintenance activities would be corrected by replanting. Part of the total expected subsidence may have taken place by the end of the active institutional control period. Therefore, the cover will have to be of adequate thickness to accommodate some, but perhaps not all, subsidence over time. The monolayer-ET cover design will be structurally stable in that it does not include layers that if displaced will render the cover ineffective. Although the cover itself is expected to erode (depressions will fill with sediment eroded from surrounding areas of the cover), the closure cove design will include properly engineered surface and side slopes, and perhaps limited armoring, to permit drainage without channelized erosion.

\subsubsection{Inadvertent Intruder Barrier}

The monolayer-ET closure cover does not include a barrier against inadvertent human intrusion (IHI). The thickness of the cover provides partial protection, but the greatest reliance is placed on a small probability of this occurrence and on institutional controls. The probability of IHI was the subject of an investigation of site-specific scenarios for IHI into waste disposed at the Area 3 and Area 5 RWMSs. The intrusion scenarios focused on drilling for water in both Yucca Flat and Frenchman Flat, driven by an individual homesteader scenario and several community settlement scenarios (Black et al., 2001). A panel of SMEs, convened to elicit the probability of IHI into a waste unit, considered the effectiveness of management controls on reducing the probability of intrusion. Management controls, which include institutional control, site knowledge, placards and markers, and surface and subsurface barriers, were thought by the panel to be effective only for the first few centuries. Some controls were considered to be more effective than others. For example, surface barriers could effectively control siting of a drill rig over a waste unit, whereas subsurface barriers and placards and markers were much less likely to control drilling. Remoteness and harsh environmental conditions of both Yucca Flat and Frenchman Flat, and the presence of playas and subsidence craters, were thought by the SME panel to be the most important factors affecting the probability of drilling, and thus intrusion. One of several community scenarios (a community settlement that develops from an industrialtechnological complex in a nearby, yet more accessible valley, and has commuter homesteaders living in Frenchman Flat) yielded the greatest probability of inadvertent intrusion, at about 10 percent. 


\subsection{Waste Characteristics}

Radiological waste from the DOE Complex is accepted at the NTS for disposal. Discussion below describes the containers, any treatment or processing prior to disposal, and the inventory of wastes.

\subsubsection{Waste Containers}

Waste is generally delivered to the Area 3 RWMS in cargo containers, metal boxes that measure

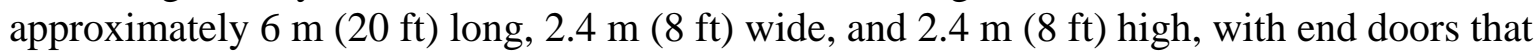
swing for access or removable tops for loading. These containers are off-loaded and disposed without opening. Waste is also delivered to the RWMS in soft-sided packages. These containers are also off-loaded and disposed without opening. Unpackaged bulk waste was placed in tiers

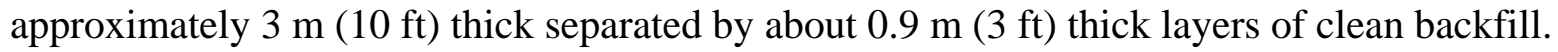
Shott et al. (2000) provides a detailed description of waste operations.

\subsubsection{Treatment or Processing Prior to Disposal}

Treatment or processing of waste is conducted by the waste generator prior to shipment to the RWMS for disposal. Generators desiring to ship waste to the NTS must have their waste certification program and waste stream(s) approved by NNSA/NSO. A waste stream is described on a waste profile. In addition to a description of the waste, a waste profile includes a description of the waste generation processes and an estimate of the low and high activity concentration of significant radionuclides. Approval to ship is granted on a waste-streamspecific basis once a generator's certification program has been approved. Waste shipped to the NTS for disposal must meet the requirements of the NTSWAC (NNSA/NSO, 2006). Information on characterization of radiological waste is reported to the site operator, generally electronically, for entry into the site inventory at the time of shipment.

\subsubsection{Waste Inventory}

The latest closure inventory estimate for the Area 3 RWMS was made, with all disposals through June 30, 2006 included, and assuming no future disposals, and summarized in the 2006 Annual Summary Report (NSTec, 2007d).

Since no estimates of future disposals are included, the closure inventory is the current disposed inventory. This closure inventory was prepared using the Area 3 Inventory v2.010 GoldSim ${ }^{\circledR}$ model. The model estimates the inventory of wastes disposed before and after September 26, 1988. Pre-1988 waste was disposed mostly in U-3ax/bl and a small amount was disposed in U-3ah/at. The total pre-1988 inventory consists of approximately 326 Terabecquerel (TBq) $(8,810.8 \mathrm{Ci})$ in $2.3 \times 10^{5} \mathrm{~m}^{3}\left(8.1 \times 10^{6} \mathrm{ft}^{3}\right)$ of waste. 
The post-1988 waste is disposed in U-3ah/at and U-3bh. The post-1988 inventory is estimated to consist of approximately $3.2 \times 10^{4} \mathrm{TBq}\left(8.65 \times 10^{5} \mathrm{Ci}\right)$ in $3.3 \times 10^{5} \mathrm{~m}^{3}\left(1.2 \times 10^{7} \mathrm{ft}^{3}\right)$ of waste. On an activity basis, the inventory is predominantly ${ }^{3} \mathrm{H}$. The FY 2006 inventory and volume estimates are reduced from previous years' estimates due to the suspension of operations before the U-3ah/at and U-3bh disposal units were filled. 
This Page Intentionally Left Blank 


\subsection{TECHNICAL APPROACH TO CLOSURE}

\subsection{Compliance with Performance Objectives and Other Requirements}

U-3ah/at and U-3bh units are operated and will be closed in accordance with the Performance Objectives set forth in DOE O 435.1 (DOE 2001). The Performance Objectives require that: (1) Dose to representative members of the public shall not exceed 25 mrem in a year total effective dose equivalent from all exposure pathways, excluding the dose from radon and its progeny in air; (2) Dose to representative members of the public via the air pathway shall not exceed 10 mrem in a year total effective dose equivalent, excluding the dose from radon and its progeny; and, (3) Release of radon shall be less than an average flux of $20 \mathrm{pCi} / \mathrm{m}^{2} / \mathrm{s}$ at the surface of the disposal facility; alternately, a limit of $0.5 \mathrm{pCi} / \mathrm{L}$ of air may be applied at the facility boundary. The Order also requires, for purposes of establishing limits on radionuclides that may be disposed near-surface, assessments of impacts to water resources and to hypothetical inadvertent intruders. Closure activities are designed to ensure compliance with these Performance Objectives. The PA results are summarized in Table 4.1 (disposed inventory through FY 1995).

Table 3.1 Performance Objectives and Results of the Area 3 RWMS Performance Assessment

\begin{tabular}{l|l}
\hline \multicolumn{1}{c|}{ Performance Objective } & \multicolumn{1}{c}{$\begin{array}{c}\text { Area } 3 \text { RWMS PA results } \\
\text { (maximum values unless specified } \\
\text { otherwise) }\end{array}$} \\
\hline $\begin{array}{l}25 \mathrm{mrem} / \mathrm{yr}, \text { member of public, all-pathways } \\
\text { dose }\end{array}$ & $\begin{array}{l}0.0009 \mathrm{mrem} / \mathrm{yr} ; \\
0.00004 \mathrm{mrem} / \mathrm{yr} \text { (mean) }\end{array}$ \\
\hline $\begin{array}{l}10 \mathrm{mrem} / \mathrm{yr}, \text { member of public air pathway } \\
\text { dose }\end{array}$ & $\begin{array}{l}0.0004 \mathrm{mrem} / \mathrm{yr} ; \\
0.00003 \mathrm{mrem} / \mathrm{yr} \text { (mean) }\end{array}$ \\
\hline Average annual ${ }^{222} \mathrm{Ra}$ flux $<20 \mathrm{pCi} / \mathrm{m}^{2} / \mathrm{s}$ & $0.1 \mathrm{pCi} / \mathrm{m}^{2} / \mathrm{s} ;$ \\
\hline Protection of Groundwater Resources & $0.02 \mathrm{pCi} / \mathrm{m}^{2} / \mathrm{s}$ (mean) \\
\hline $500 \mathrm{mrem}$ Acute- inadvertent human intrusion & No Release \\
\hline $\begin{array}{l}100 \mathrm{mrem} / \mathrm{yr} \text { Chronic- inadvertent human } \\
\text { intrusion }\end{array}$ & $0.04 \mathrm{mrem}$ (mean) \\
\hline
\end{tabular}

\subsubsection{All-Pathways Dose}

As shown in the PA (Shott et al., 2000), the calculated dose from the all-pathways compliance scenario for the U-3ax/bl and U-3bh units is well below the performance objective. The doses are primarily associated with combined upward liquid and vapor fluxes, and biotic transport from the disposal units (Table 3.1). Cover thickness is a primary variable in the prediction of the doses to a member of public. 
The PA evaluated a 3-m closure cover over the disposal units, with the 1999 estimate of the closure cover inventory. Although the closure inventory has changed since the PA, preliminary results shown in the 2006 annual summary report indicate that the all-pathways dose will remain well below the performance objective. A PA revision will be performed in FY 2008, using the updated version of the Area 3 RWMS GoldSim PA/CA model. The model will include the consequences of unit subsidence and the latest closure inventory.

The all-pathways dose result for the final PA is expected to remain well below the performance objective. Optimization of the cover thickness, which will be performed using the Area 3 RWMS GoldSim PA model, may lead to a cover thickness less than $3 \mathrm{~m}(10 \mathrm{ft})$.

\subsubsection{Air Pathway Dose}

As shown in the PA (Shott et al., 2000), the calculated dose from the air pathway for the $\mathrm{U}-3 \mathrm{ax} / \mathrm{bl}$ and U-3bh units is well below the performance objective (Table 4.1). Cover thickness is the primary factor in the calculation of the air dose.

Preliminary results shown in the 2006 annual summary report indicates that air pathway dose will remain well below the air performance objective. With the optimized cover thickness, the air pathway in the final PA is expected to be below the air performance objective.

\subsubsection{Radon Flux}

The cover thickness is the primary factor in the calculation of the radon flux, with greater cover thickness resulting in greater diffusion path length and reduction in radon flux. The PA radon flux result is well below the radon performance objective (Table 3.1), and is expected to remain so in the final PA using an optimized cover thickness.

\subsubsection{Other Requirements}

\subsubsection{Groundwater Resource Protection}

The site conceptual model that was developed based on multiple lines of evidence derived from the several decades of site characterization activities and vadose zone modeling of flow and transport does not include a groundwater pathway. Therefore, the Area 3 RWMS PA was based on no groundwater pathway.

No impact to the groundwater from the disposal activities at the Area 3 RWMS is expected over the compliance period. Therefore, the closure system design has no special provisions for groundwater protection, other than the cover thickness, which assures minimal contact of water with the waste zone. 


\subsubsection{Inadvertent Human Intrusion}

The consideration of IHI has no relevance for the Area 3 RWMS closure cover system design other than the cover thickness. The Area 3 RWMS PA evaluated two acute and chronic IHI scenarios: the intruder-agriculture scenario where intruder constructs a residence with basement over the cover, and the post-drilling scenario, in which a water well is drilled through the cover and the waste zone to the water table below. Basement construction associated with the agriculture scenario dictated a minimum cover thickness of $3 \mathrm{~m} \mathrm{(10} \mathrm{ft)} \mathrm{to} \mathrm{avoid} \mathrm{excavation} \mathrm{into}$ the waste zone when a basement construction takes place. Cover thickness has no relevance for the drilling scenario. The PA took credit for the probability of intrusion into the RWMS in evaluating the IHI doses.

In the update of the PA in FY 2008, only acute intrusion scenarios will be considered recognizing NNSA/NSO's refined institutional control policies for the NTS disposal facilities, which preclude chronic scenarios (see Section 3.2.3).

\subsection{Detailed Closure Activities}

Closure of the Area 3 RWMS includes operational closure followed by final closure. Operational closure provides the initial protection and containment of disposed waste containers. Final closure provides containment of disposed wastes for an indefinite period.

\subsubsection{Operational/Interim Closure}

Waste at the Area 3 RWMS is disposed in tiers. Tiers are necessary to keep the height of stacked waste packages low to ensure worker safety. Depending on the disposal unit, a tier may consist of unpackaged bulk waste (U-3ax/bl), waste soil in soft-sided packages (U-3bh), or packaged waste (U-3ah/at). As a tier of waste is placed from one side of the unit toward the other side, the

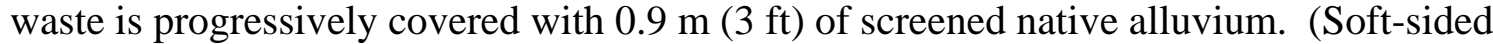
packages are covered with $0.3 \mathrm{~m}$ [1 ft] of alluvium.) Each tier, when complete, extends over the entire floor of the disposal unit. The current disposal units at the Area 3 RWMS will be operationally closed above grade. Alternating tiers of waste and alluvium will be brought to within $1.2 \mathrm{~m}(4 \mathrm{ft})$ of grade.

Disposal unit U-3ax/bl is the only unit at the Area 3 RWMS to have been filled and closed. The other two active disposal units are partially filled. Before final closure, the operational cover on $\mathrm{U}-3 \mathrm{ax} / \mathrm{bl}$ was less than $1 \mathrm{~m}$ (3 ft) above grade. Until recently, little was known of the construction of the operational cover because at the time of closure, a recognized closure program was not in place. A ground-penetrating radar survey of the cover conducted in November 1999 showed the top $1.2 \mathrm{~m}(4 \mathrm{ft})$ to be homogeneous, and the interval between 1.2 and $3 \mathrm{~m} \mathrm{(4} \mathrm{and} 10 \mathrm{ft}$ ) to be slightly heterogeneous but relatively free of disposed waste (DOE,

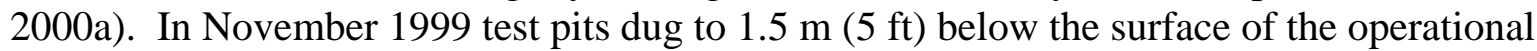

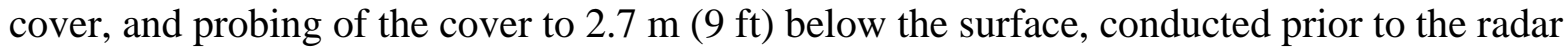
survey, corroborate results of the radar survey. Most dry densities of samples collected from the 
test pits ranged between 1.4E03 and 1.9E03 kilograms $/ \mathrm{m}^{3}$ (90 and 110 pounds/ft ${ }^{3}$ ). Calculated permeabilities of samples ranged between 1.00E-3 and 1.00E-6 cm/s (4.00E-4 and 4.00E-7 in./s), with the mean permeability being approximately 1.00E-5 cm/s (4.00E-6 in/s) (DOE, 2000a). These ranges of values for density and permeability are generally representative of all the operational closure covers because the method of placing the operational cover is generally the same between units and between the two RWMSs. Determining density and permeability on operationally closed disposal units will be part of the final closure process.

Modeling conducted for the final closure of disposal unit U-3ax/bl shows that water is effectively removed from the soil column with as little as 20 percent vegetation cover (DOE, 2000a). Several instrumented drainage lysimeters have been installed at the Area 3 RWMS for further verification and, thus far, have been responding according to the predictions of the model.

\subsubsection{Final Closure}

Waste disposal unit U-3ax/bl was closed according to RCRA requirements in FY 2001. A nominal $0.3 \mathrm{~m}(1 \mathrm{ft})$-thick monolayer-ET closure cover composed of locally derived soil was placed over an existing above-grade operational closure cover, providing approximately $3 \mathrm{~m}$ $(10 \mathrm{ft})$ of cover over the waste zone. The ET closure cover was graded and then vegetated with local species by both seeding and planting. The cover is being monitored with time-domain reflectometry (TDR) nests in four locations, as agreed upon with the NDEP.

The closure cover concept of U-3ax/bl is also adopted for the closure covers for U-3bh and U-3ah/at. Title II (85 percent complete) engineering cover designs for these units are presented in Appendix A of this plan.

Design features and design criteria are summarized below.

\subsubsection{Cover Thickness}

A final closure cover thickness of $3 \mathrm{~m}(10 \mathrm{ft})$ is deemed adequate to meet the PA performance objectives. This thickness, which includes the thickness of the operational covers, is the minimum thickness of cover over the waste across the cover. It may be greater than $3 \mathrm{~m} \mathrm{(10} \mathrm{ft)} \mathrm{at}$ certain locations over the cover in order to accommodate the design cover slopes.

\subsubsection{Cover Slope}

The top surface of the cover is sloped sufficiently (approximately 0.75 percent for U-3ah/at and 0.5 percent for U-3bh) to provide free drainage without ponding of water while minimizing erosion due to runoff. The cover side slopes are 1 vertical to 10 horizontal. The surface slope and cover side slopes for the final design will be established to minimize erosion and the need for side slope armoring. 


\subsubsection{Cover Material}

Materials for constructing the cover will be natural soils obtained from designated NTS borrow sources located in the vicinity of the RWMS and from other NTS borrow sources. The soils will be compatible with the materials used for the operational covers. If necessary, soil samples may be collected and analyzed using the following methods to determine suitability based on the PA and comparability with existing operational covers:

- American Society for Testing and Materials (ASTM) D422: Standard Test Method for Particle-Size Analysis of Soils

- ASTM D854: Standard Test Methods for Specific Gravity of Soil Solids by Water Pycnometer

- ASTM D1557: Standard Test Methods for Laboratory Compaction Characteristics of Soil

- $\quad$ ASTM D2216: Standard Test Method for Laboratory Determination of Water (Moisture) Content of Soil and Rock by Mass

- $\quad$ ASTM D2434: Standard Test Method for Permeability of Granular Soils

- $\quad$ ASTM D2487: Standard Classification of Soils for Engineering Purposes (Unified Soil Classification System)

- ASTM D2922: Standard Test Methods for Density of Soil and Soil-Aggregate in Place by Nuclear Methods (Shallow Depth)

- $\quad$ ASTM D4318: Standard Test Methods for Liquid Limit, Plastic Limit, and Plasticity Index of Soils

- $\quad$ ASTM D5084: Standard Test Methods for Measurement of Hydraulic Conductivity of Saturated Porous Material Using a Flexible Wall Permeameter

- $\quad$ ASTM D6527: Standard Test Method for Determining Unsaturated and Saturated Hydraulic Conductivity in Porous Media by Steady-State Centrifugation

\subsubsection{Cover Infiltration}

Infiltration of water into the waste zone below the cover is minimized by planting native vegetation on the cover, sloping the cover, and providing an adequate cover thickness. The concept of the cover design is such that evapotranspiration is the driving mechanism for removing moisture from the cover. Sloping minimizes ponding and reduces infiltration by promoting water flow off the cover, and cover thickness provides the necessary storage for moisture. 


\subsubsection{Cover Erosion}

Erosion will be controlled through a combination of vegetation and cover slope. Limited armoring (such as rip-rap) may be installed on the cover side slopes to prevent erosion.

\subsubsection{Cover Subsidence}

Subsidence could occur due to infilling of void spaces around containers, plus the degradation and subsequent collapse of buried waste containers. The cover design (monolayer) is sufficient to maintain structural stability in the event of incidental subsidence. Subsidence or localized settling would be mitigated shortly after discovery.

\subsubsection{Cover Vegetation}

Vegetation is an integral component of cover design and minimizes both infiltration and erosion. The cover will be seeded and/or planted with plant species native to the area in a density similar to natural conditions. The surface of the cover will be disked to a depth of approximately $0.3 \mathrm{~m}$ $(1 \mathrm{ft})$ prior to seeding. Short-term irrigation may be required to accelerate seed germination and rooting until vegetation is established.

\subsubsection{Cover Monitoring}

Individual closure covers will not be monitored since the Area 3 drainage lysimeter facility will serve as a surrogate monitoring station.

\subsubsection{Drainage}

The Area 3 RWMS is currently surrounded by a non-engineered soil berm. The need for additional protection from flooding caused by upstream areas outside the RWMS will be based on the results of further flood studies. Flooding within the RWMS will be controlled by the cover-slope design, in conjunction with new engineered drainage channels, to direct run-off away from the closure covers and ultimately outside the RWMS.

\subsubsection{Institutional Control}

The following institutional controls currently in place for the Area 3 RWMS will continue to be implemented during post-closure:

- Access controls and site security provided through government control of the NTS. 
- Agreements and discussions with the Nellis Air Force Range (also known as the Nellis Test and Training Range), the Bureau of Land Management, the U.S. Fish and Wildlife Service, and the NDEP regarding long-term ownership and control of the lands including and surrounding the NTS

- Maintenance operations, remedial actions, and decommissioning steps necessary to establish the proper post-closure condition for the site

- Monitoring of parameters related to performance of waste disposal systems

- Implementation of specific controls: (a) fences and signs, (b) facility guards for roadways, and patrols, (c) land use control and permits, (d) land reclamation, (e) inspection and maintenance, and (f) reporting of activities and incidents that impact access control and security, and any corrective actions

The length of the institutional control period was treated probabilistically in the Area 3 RWMS PA. A probability distribution was assigned to the length of the institutional control period based on the results of an expert judgment elicitation of the probability of IHI. Human intrusion was assumed to occur (probability $=1$ ) after loss of institutional control (Black et al., 2001). The PA also weighted the dose to inadvertent intruder by the probability of IHI.

In response to concerns over consistency issues in institutional control and land use policies implemented in the NTS PAs/CAs, the NNSA/NSO conducted an evaluation of program assumptions across the waste management and environmental restoration programs. As a result, a new institutional control policy was developed and expected to be formally adopted in FY 2008. An unpublished position paper on the NNSA/NSO's institutional control policy and its implementation in the future PAs/CAs at the NTS is available (Crowe et al., 2007). The following summary is from this position paper:

- Timing of the onset of the loss of active institutional control will continue to be assessed as a probability distribution that is based on and justified by local conditions.

- The probability of IHI will no longer be applied in risk-modified dose calculations consistent with the guidance of the National Academy of Science.

- $\quad$ The Area 5 and Area 3 facilities will assume land-use restrictions consistent with NNSA directives and the UGTA/FFACO policies for the NTS.

- The land use restrictions will prohibit public access to contaminated groundwater within the NDEP compliance-negotiated boundaries for 1,000 years. 1,000-yr duration for land-use restrictions is not specified in the FFACO (2004) but is a recognized requirement of the definition of the contaminant boundary (page VI-3-3), the performance criteria (page VI-34) and the requirements for implementing the Safe Drinking Water Act (page VI-3-12; (all page references from Appendix VI of the FFACO [2004]). 
- The PA and CA for the Area 5 and Area 3 facilities demonstrate that there is insufficient transport to establish a downward pathway beneath the facilities to groundwater for contaminants during the 1,000-year compliance period (Shott et al., 1998, 2001; BN and Neptune, 2006). The only release pathways that allow interaction between the disposal facility inventory and the UGTA groundwater contamination is from drilling to groundwater near the waste disposal facilities (combined atmospheric and groundwater pathways).

The land use restrictions are assumed to eliminate long-term access to groundwater for the chronic post-drilling and intruder agriculture scenarios. The policies are not expected to be $100 \%$ effective for shorter time spans (months) and will not prevent the acute groundwater drilling and construction scenarios.

Consistent with this policy, the next update of the Area 3 RWMS PA will evaluate acute drilling and construction IHI scenarios. The acute drilling scenario estimates the dose to a drill crew drilling a water well through a disposal cell. The acute construction scenario estimates the dose to a construction crew excavating a septic tank or basement during construction of a residence. The PA will assume the member of public to be located $100 \mathrm{~m}$ from the facility boundary and continue to use the probability distribution for the onset of loss of institutional controls. Cover thickness optimization for the disposal units will be based on this new set of assumptions.

\subsubsection{Post-Closure Care and Strategy}

Post-closure care of the U3-ax/bl will be conducted for a minimum of 30 years. Following certification of closure of the Area 3 RWMS LLW units, according to DOE O 435.1 and DOE M 435.1-1, the facilities will be subject to post-closure care for a period of time yet to be determined in the final closure plan. The NNSA/NSO position is that the NTS will be controlled in perpetuity. However, should this position change for part or all of the NTS, institutional control shall continue until the facility can be released pursuant to DOE O 5400.5, Change 2, "Radiation Protection of the Public and Environment."

\subsection{Site Inspection and Maintenance}

The inspection program addresses inspection requirements for environmental monitoring equipment, fire protection systems, safety and emergency equipment, security devices, and operating or structural equipment that are critical to prevent, detect, or respond to human health or environmental hazards. Records will be maintained by the RWMS personnel for tracking purposes to ensure that inspections are conducted according to established schedules.

Inspections will consist of visual observations to ensure that closure cover integrity is maintained and fencing and boundary monuments are intact. Inspections and associated repairs will ensure the continuing protection of human health and the environment. 
Post-closure inspection and maintenance will be minimized to the extent possible by the design of the closure cover system and additional site security measures. Post-closure inspections and maintenance activities will include the following:

- General Facility Inspection: visually inspect condition of fences, gates and locks for breaks, gaps, and damage; inspect monuments for condition and legibility; confirm that gates properly close and lock; and inspect condition of vegetative cover.

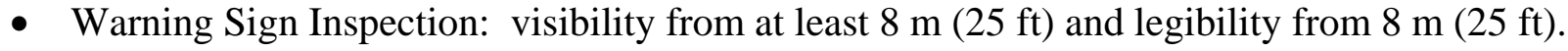

- Cover Inspection: observe cover for erosion, settlement, subsidence, displacement, burrowing, and plant growth.

- Run-on/Runoff Inspection: visually inspect control structures and drainage system for presence of erosion and shifting from storms or precipitation.

- Maintenance activities will be based on inspection results. Custodial maintenance or repair actions may include repairing of fences, replacing warning signs, re-establishing location control monuments, removing unwanted vegetation, reconstructing slopes, covers, or embankments.

- The condition of any surveyed subsidence marker will be inspected every six months. In addition, all survey markers will be resurveyed on an annual basis to determine if the covers have subsided.

- A survey of the boundary monuments regarding their placement and verification of the condition of each boundary marker will be performed. Any problems will be noted on the inspection form and repairs made.

- During each inspection, any changes in the condition of the closure cover, vegetation, or fenced area will be documented. Specific changes noted on the current condition of the cover include, but are not limited to, trash and debris within the fenced compound, animal burrows or nesting activity, and erosion of the cover.

- Cracks or settling imperfections of 2.5 to $15 \mathrm{~cm}$ (1 to 6 in.) deep on the cover will be documented and scheduled for repair on an annual basis. No action will be taken for cracks or settling imperfections of less than $2.5 \mathrm{~cm}$ (1 in.). Larger disruptions of the cover (animal diggings or erosion) will be immediately evaluated, repaired within 90 days, and documented.

All repair work to the cover will ensure that the integrity of the cover and design is maintained "as built." For RCRA-regulated disposal units, if cover repair requires modifications of the closure-cover design, NNSA/NSO will present a formal design modification request to the NDEP prior to making the design modification.

All repair work to any closure cover will ensure that the integrity of the cover and design 
is maintained "as built." If closure cover repairs require modifications of the cover design, NNSA/NSO will present a formal design modification request to the NDEP prior to making the design modification.

Closure and post-closure monitoring documentation will be maintained in the Area 3 RWMS files and at the NNSA/NSO Technical Library in North Las Vegas. The files will be available for inspection and review upon request.

\subsection{Protection from Adverse Impact}

Protection of the groundwater, human health, and the environment are primary concerns following final closure of the Area 3 RWMS. The following sections discuss measures to ensure that these resources are not adversely impacted by the facility.

\subsection{Groundwater}

Sections 2.1.4 and 2.1.5, which include discussions of the geology and hydrology of the sites and how moisture migrates through the unsaturated zone, demonstrate that past, current, and future operations at the Area 3 RWMS will not impact the underlying groundwater in the AA.

Performance monitoring of the unsaturated zone during the operational phase of the RWMSs has

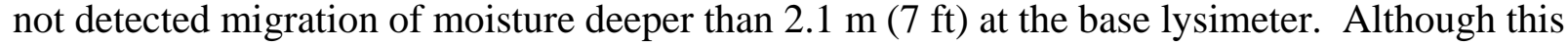
does not reflect evapotranspiration of vegetated landfill cover, no impact to the groundwater has occurred using the current design of the disposal units. During the closure and post-closure phase, the design of the closure cover and drainage system limits infiltration to less than that during operations and prevents water runoff.

No impact to the AA is expected because the combination of low precipitation and high potential evapotranspiration induces slow upward migration of moisture within the unsaturated zone from as deep as about $35 \mathrm{~m}(115 \mathrm{ft})$. The average upward velocity of liquid movement is about $0.03 \mathrm{~mm} / \mathrm{yr}(0.0012 \mathrm{in.} / \mathrm{yr})$. The waste zone and closure cover are in the region of upward flow. Because the depth to groundwater exceeds $488 \mathrm{~m}(1,601 \mathrm{ft})$ at the Area 3 RWMS (NSTec, 2007b), the potential for liquid migration from the disposal units is zero.

The Area 3 RWMS is located in thick, unsaturated, alluvial deposits. The hydrological properties of alluvium below the RWMSs have been established through extensive site characterization studies and have been summarized in Section 2.6 of this report.

The hydrologic setting of the Area 3 RWMS is such that the probability of leachate formation or hazardous components from wastes in regulated disposal units reaching groundwater during the active life of the units and the post-closure care period is negligible. This is shown in an evaluation of the unsaturated hydraulic conductivity as compared with saturated hydraulic conductivity requirements in the regulations. A low unsaturated hydraulic conductivity of $<10^{-7}$ $\mathrm{cm} / \mathrm{s}$ is one landfill design criterion for successfully restricting the migration of contaminants. 
Kearl (1982) provides an unsaturated hydraulic conductivity versus water-content chart for alluvial soils at the site. Using average volumetric-moisture content for the site of 8.7 percent and a soil porosity of 30 percent, the unsaturated hydraulic conductivity for the site soils is approximately $10^{-10} \mathrm{~cm} / \mathrm{s}$, or three orders of magnitude below the regulatory requirement. At depths as shallow as $10 \mathrm{~m}$ (32.8 ft) below the land surface, moisture contents drop below 5 percent, decreasing the unsaturated hydraulic conductivity to less than $10^{-12} \mathrm{~cm} / \mathrm{s}$. Both of these unsaturated conductivities are probably indicative of moisture contents where the interconnection of liquid water ceases, thus preventing the migration of liquids. There is a large potential soil moisture storage capacity in this thick, dry alluvial static zone.

Performance monitoring within the closure cover of U-3ax/bl and at representative drainage lysimeters adjacent to the disposal units will provide data on the moisture content of soils and the potential for downward or upward movement of liquids. By conducting performance monitoring, any potential changes in moisture content will be detected and appropriate remedial measures implemented to prevent continued downward movement of liquid.

\subsection{Human Health and Environment}

The Area 3 RWMS will be monitored and inspected during the closure and post-closure care periods to ensure public safety and human health and to prevent damage to the environment. The monolayer-ET closure cover design does not include a barrier against IHI. The thickness of the cover provides partial protection, since significant effort must be undertaken to expose the waste zone. Site security, long-term institutional control, and controlled facility access will prevent human intrusions.

\subsection{Site Security}

The security plan for the Area 3 RWMS will be part of the final closure plan. The disposal areas currently are secured 24 hours a day, 7 days a week. Security is maintained with the following systems:

- Access requiring prior authorization and an escort, if not previously authorized to enter

- Perimeter markers, a perimeter fence, and gated access road to the disposal-unit area, with postings of the hazards and access requirements

The fences will prevent access to most animals to eliminate their ingestion of the native vegetation, while keeping unauthorized personnel from performing intrusive activities at the site.

Overall security at NTS is maintained 24 hours, 7 days a week by highly trained security personnel. Security of the Area 3 RWMS will continue during the post-closure care period and will include the following:

- Posted warning signs designating site dangers 
- Fences to keep out unauthorized personnel

- Controlled site access for specific disposal units

- Perimeter inspections to check for signs of intrusion or fence deterioration/damage

\subsubsection{Unrestricted Release of Sites}

Public access to the NTS is currently restricted and will continue to be restricted as long as the NTS has an active national security mission. An active national security mission is assumed into the foreseeable future. If the NTS national security mission ends, the release of NTS land for public access will be constrained by historical contamination from atmospheric nuclear testing, underground nuclear testing, nuclear rocket testing, and radioactive waste disposal. Remediation and closure of historically contaminated sites on the NTS is regulated by the FFACO (2004) between the NNSA/NSO, the state of Nevada, and the U.S. Department of Defense. The FFACO defines a RCRA-like process for remediation and closure of CAUs and requires the state of Nevada to review and approve all corrective actions. Release of land for public access is also subject to the requirements of DOE O 5400.5, Change 2.

The NNSA/NSO has implemented the UGTA Program and the Environmental Restoration Project (Soils Project) to close UGTAs and contaminated soil sites under the FFACO (2004). The remediation option for UGTA closures that is accepted by the state is identification of areas within the NTS where public access or groundwater use will be restricted in perpetuity. The dose to a future member of the public who may have access to lands in Yucca Flat has been evaluated in the CA for the Area 3 RWMS. The CA considered all sources of residual radioactive material, assuming that the soils sites may not be cleaned up and restricted areas that will be identified by the UGTA program will be in effect, and showed that a cumulative dose to a member of the public who resides in Yucca Flat will be below the CA dose limit of $100 \mathrm{mrem} / \mathrm{yr}$ and dose constraint of $30 \mathrm{mrem} / \mathrm{yr}$. The current CA does not show the extent of the restricted areas. The restricted areas will be incorporated into the CA under the PA Maintenance Plan when the UGTA Program completes the necessary site characterization and modeling and the boundaries of the restricted areas are agreed upon between the state of Nevada and the NNSA/NSO. The Corrective Action Decision Document identifying the UGTA CAU boundaries is expected to be finalized in FY 2020.

\subsection{Monitoring}

Monitoring at the Area 3 RWMS is required under a variety of regulatory drivers, including federal regulations and DOE orders. Monitoring data are used for the following:

- Demonstrate compliance with regulatory drivers

- Evaluate radiation doses to the general public

- Confirm PA conceptual models

- Confirm soil-water contents used in the PA 
- Confirm PA assumptions about flux rates through upward and downward pathways

Monitoring is also conducted to ensure the integrity of covers over waste disposal units. The monitoring program is designed to sufficiently forewarn management and regulators of any need for mitigative actions and to record the utility of any mitigative actions.

Review of monitoring data for routine PA and CA maintenance is an iterative process that will ultimately dictate which monitoring data should continue to be collected during the post-closure care period, and which monitoring data are no longer required.

The Routine Radiological Environmental Monitoring Plan (RREMP) (BN, 2003a) brings together sitewide environmental surveillance, site-specific effluent monitoring, and operational monitoring conducted by various missions, programs, and projects on the NTS. The plan provides an approach to identifying and conducting routine radiological monitoring at the NTS, based on integrated technical, scientific, and regulatory compliance data needs. The RREMP uses a decision-based approach to identify the environmental data that must be collected and provides Quality Assurance, Analysis, and Sampling Plan which ensures that defensible data are generated. The approach is based on a modification of the EPA's Data Quality Objective (DQO) process (EPA, 1994), a seven-step process that calls for identification of the decisions that data collection activities must support, and uses a logical structure to develop the plan for data collection and analysis.

The detailed steps of the process for each media are presented in Appendix E of the RREMP. During the design process, existing and historical site information and regulatory requirements were reviewed. A summary of the site characteristics, transport and exposure pathways, regulatory requirements, and historical data were evaluated for each medium in preparation of the RREMP to support the monitoring designs.

\subsubsection{Operational/Interim Closure}

A summary of the current monitoring activities is shown in Table 3.2. The results of these activities are reported in the Annual Waste Management Monitoring Report (NSTec, 2007c) and the Nevada Test Site Environmental Report (NTSER) (NSTec, 2006), which was formerly called the Annual Site Environmental Report.

These activities summary follows.

\subsubsection{Monitoring Elements}

\subsection{Direct Radiation Monitoring}

The direct radiation monitoring is conducted to confirm that RWMS activities do not result in significant exposure above background levels, in compliance with DOE O 450.1, DOE O 5400.5, 
and DOE O 435.1, and the Environmental Regulatory Guide for Radiological Effluent Monitoring and Environmental Surveillance (DOE, 1991).

Figure 3.1 shows thermoluminescent dosimeter (TLD) locations at the Area 3 RWMS. Details of the direct radiation monitoring activities can be found in the NTS Routine RREMP and Organization Instruction OI-2154.109, "Radiation Monitoring Using Thermoluminescent Dosimeters.”

\section{Table 3.2 Monitoring Activities at the Area 3 Radioactive Waste Management Site}

\begin{tabular}{|c|c|}
\hline Monitoring Element & \\
\hline Direct Radiation Monitoring & Ten thermoluminescent dosimeters (TLDs) \\
\hline Air Monitoring & Four air particulate and two tritium stations \\
\hline Radon Monitoring & Radon flux measurements on the U-3ax/bl cover \\
\hline Meteorology Monitoring & $\begin{array}{l}\text { - air temperature at two heights } \\
\text { - relative humidity at two heights } \\
\text { - wind speed at two heights } \\
\text { - wind direction at two heights } \\
\text { - barometric pressure } \\
\text { - solar radiation } \\
\text { - precipitation }\end{array}$ \\
\hline Vadose Zone Monitoring & $\begin{array}{l}\text { - measurements of soil-water content and water } \\
\text { potential in U-3ax/bl waste disposal unit cover } \\
\text { - drainage lysimeter facility }\end{array}$ \\
\hline Biota Monitoring & Sampling vegetation for tritium \\
\hline Subsidence Monitoring & $\begin{array}{l}\text { Routine inspections of operational covers for } \\
\text { subsidence features such as cracks, depressions, } \\
\text { ponding, and erosion }\end{array}$ \\
\hline
\end{tabular}

\subsection{Air Monitoring}

The regulatory drivers for the air monitoring network include Title 40 CFR 61, Subpart H; DOE O 450.1; DOE O 5400.5; and Guidance Document DOE/EH-0173T (DOE, 1991). Details of the DQO, sampling strategy, field operations, analytical design, analytes, and methods, and quality control checks are described in Appendix A of the RREMP (BN, 2003a). Air particulate samples are collected using continuously operated low-volume air samplers and are analyzed for gross alpha/beta radioactivity, gamma emitters, americium, and plutonium concentrations in air. Atmospheric moisture is collected and analyzed for tritium. Tritium is a volatile radionuclide and is therefore a conservative indicator of waste-disposal unit performance.

Air particulate samples are collected at air sampling stations at two locations at the Area 3 RWMS. Atmospheric moisture is not collected at the Area 3 RWMS because of the small tritium inventory. Figure 3.1 shows locations of air samplers. 
Siting of the air samplers was based on the RREMP DQO process. Important siting decision factors included wind patterns and historic analytical data. In Area 3, wind direction is generally northerly or southerly. Therefore, air sampling stations are sited at locations north and south of each of the active disposal units, U-3ah/at and U-3bh.

Annual air monitoring data are reported in the NTSER (NSTec, 2006), the National Emissions Standards for Hazardous Air Pollutants (NESHAP) report (NSTec, 2007e), and the Annual Waste Management Monitoring Report (NSTec, 2007c).

Details of the RWMS air monitoring activities are in Appendix A of the RREMP (BN, 2003); NSTec Organization Instructions (OI) OI-2154.102, "Preparing and Sampling Routine Radiological Environmental Monitoring Plan for Airborne Particulates”; and OI-2154.103, “Tritiated Water Vapor Sampling.” 


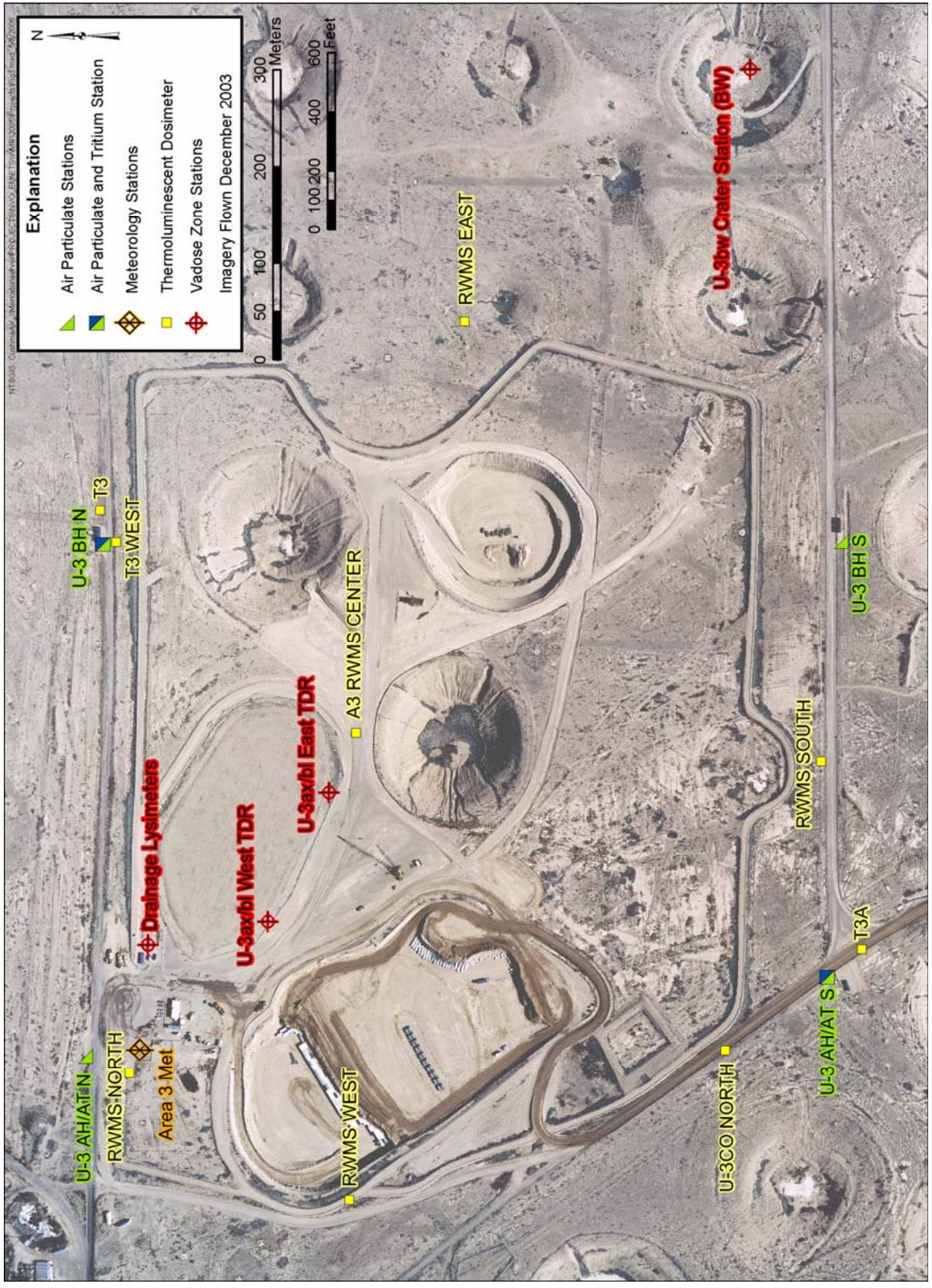

Figure 3.1 Monitoring Locations at the Area 3 RWMS 


\subsubsection{1,3 Radon Monitoring}

Yearly measurements of radon flux through the cover of U-3ax/bl is conducted using ElectretPassive Environmental Radon Monitors to determine if the fluxes are within a performance objective of $20 \mathrm{pCi} / \mathrm{m}^{2} / \mathrm{s}$ given in the Area 3 and DOE $\mathrm{O} 435.1$.

\subsection{Vadose Zone Monitoring}

Vadose zone monitoring is conducted at the Area 3 RWMS for the following:

- $\quad$ Demonstrate compliance with DOE O 450.1 and O 435.1

- Confirm PA assumptions regarding the hydrologic conceptual model including soil-water contents and upward and downward flux rates

- Test the PA performance objective of protecting groundwater resources

- Demonstrate negligible infiltration of precipitation into waste zones

- Detect changing trends in performance

- Establish baseline levels for long-term monitoring

- Comply with NDEP negotiated requirements at Area 3 RWMS, U-3ax/bl MWDU

Vadose zone monitoring is conducted by measuring all the water balance components including:

- Meteorological monitoring to measure precipitation (the driving force for downward flow) and to calculate PET (the driving force for upward flow)

- Lysimeters to measure infiltration, soil-water redistribution, bare-soil evaporation, evapotranspiration, and deep drainage.

In the past, soil moisture contents were measured using neutron logging. This has been replaced with TDR probes. Heat dissipation probes are used to measure soil-water potentials.

This strategy provides an accurate estimate of the water balance for the disposal units including any drainage through the waste covers and, therefore, potential percolation below the waste zone.

The current vadose zone monitoring program is designed based on a strong understanding of the vadose zone system from the results of extensive vadose zone characterization studies (BN, 1998c; Blout et al., 1995; REECo, 1994, 1993a, b; Schmeltzer et al., 1996; Shott et al., 1998, 2000; Tyler et al., 1996) and modeling studies (Crowe et al., 1998b; Levitt et al., 1999). In addition, the vadose zone monitoring program is designed in part from the results of an 
Alternative Evaluation Study on vadose zone monitoring (BN, 1998c) using an organized team approach and, in part, from successful vadose zone monitoring field experience.

Vadose zone monitoring data are reported in an annual monitoring report (NSTec, 2007c). Details of the RWMS vadose zone monitoring activities can be found in NSTec OI-2154.111, "Instructions for Datalogger Monitoring Stations."

Results from the U-3ax/bl automated waste cover monitoring system and from the lysimeter facilities at the NTS will help assess performance of future monolayer-ET covers at the Area 3 RWMS. To minimize penetrations in the final covers, direct monitoring of moisture conditions in the future U-3bh and U-3ah/at final landfill covers is not planned or necessary.

\subsection{Area 3 Drainage Lysimeter Facility}

In 2000, eight drainage lysimeters were constructed adjacent to the northwest corner of the U-3ax/bl disposal unit at the Area 3 RWMS (Figure 3.1). Each lysimeter is $3 \mathrm{~m}(10 \mathrm{ft})$ in diameter, $2.4 \mathrm{~m}$ (8 ft) deep, has a sealed bottom that enables direct measurement of drainage, and is instrumented with soil-water content and soil-water potential sensors at eight depths. Construction of the lysimeter facility was funded by the Accelerated Site Technology Deployment program under the DOE Office of Science and Technology. The lysimeters replicate landfill cover conditions and are surrogates for monitoring covers directly. The objective of the facility is to collect data to reduce the uncertainty associated with the performance of monolayer-ET waste covers in arid regions. This uncertainty includes waste cover vegetation type and precipitation amount. The surface treatment of the lysimeters are as follows: two lysimeters were left bare (A and B); two were allowed to revegetate with invader species (C and D); two were revegetated with native species ( $E$ and $F$ ) identical to the revegetation of U-3ax/bl; and two are reserved for future investigations ( $\mathrm{G}$ and $\mathrm{H})$, but currently treated like lysimeters $\mathrm{C}$ and $\mathrm{D}$. Lysimeters $\mathrm{B}, \mathrm{D}, \mathrm{F}$, and $\mathrm{H}$ are irrigated to receive three times the average precipitation to replicate a future, wetter climate.

\subsection{Automated Waste Cover Monitoring System}

The automated vadose zone monitoring system has provided data over a broad range of precipitation and vegetation irrigation scenarios. The results from U-3ax/bl are pertinent to the future performance of similar monolayer ET covers planned for U-3bh and U3-ah/at.

TDR probes were installed at four locations and eight depths in the U-3ax/bl waste cover in 2000, as described in the closure plan for U-3ax/bl (DOE, 2000a), and the closure report for $\mathrm{U}-3 \mathrm{ax} / \mathrm{bl}$ (NNSA/NV, 2001). Vadose zone performance monitoring of the waste cover at $\mathrm{U}-3 \mathrm{ax} / \mathrm{bl}$ is required by NDEP as described in a letter from NDEP to DOE/NV, dated February 22, 2000. Vadose zone monitoring of the $\mathrm{U}$ 3ax/bl waste cover is currently administered and conducted by NSTec Environmental Restoration (ER). 
In December 1998, heat dissipation probes were also installed in the floor of subsidence crater

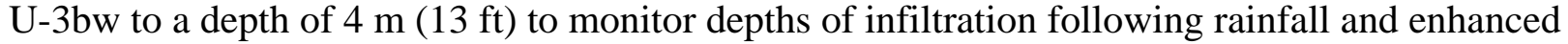

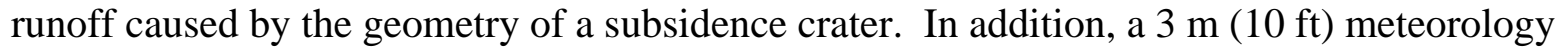
tower and a neutron logging access tube were installed at the floor of U-3bw. Data collected is used to characterize the dynamic water balance of a typical subsidence crater used for waste disposal at the Area 3 RWMS. These data are required to understand the hydrologic system of a subsidence crater for waste disposal in Area 3. Refer to Figure 3.1 for the location of U-3bw.

TDR and other types of automated vadose zone monitoring systems have been implemented at many other study sites with varying degrees of success. Some sites in which TDR or other vadose zone technologies have been used include Beatty, Nevada (Andraski, 1997); Phoenix, Arizona (Young et al., 1999); Albuquerque, New Mexico (Dwyer, 2001; Goering, 1999); Hanford, Washington (DOE, 1999b); and the Savannah River Site, Georgia (Burns, 1999).

The expected life span of these automated vadose zone monitoring systems is unknown. With routine maintenance and occasional replacement of failed components, these systems should last for years or decades. An additional consideration is that as new and improved vadose zone monitoring sensors and technologies become available, they should be implemented for redundancy or replacement of current systems wherever appropriate.

\subsection{Neutron Logging}

In the past, neutron logging was conducted at selected neutron access tubes at the Area 3 RWMS to provide profiles of soil-water content with depth and time. The automated vadose zone monitoring systems at the RWMSs have largely replaced neutron logging. Advantages of the automated system over neutron logging include lower field labor requirements and avoidance of handling a source. Infrequent neutron logging may be useful to supplement automated vadose zone systems where access tubes remain accessible. However, no neutron access tubes are anticipated to remain in the covers at closure in order to minimize potential penetration of the final cover.

At the Area 3 RWMS, deep vadose zone monitoring by neutron logging has been conducted in cased boreholes angled under the U-3ah/at and U-3ax/bl disposal units, and in cased boreholes drilled directly into the floor of the U-3bh disposal unit. These boreholes are designated U-3at-D1, U-3at-D2, U-3bh-C1, U-3bh-C2, U-3bl-D1, U-3bl-D2, and U-3bl-U1.

Area 3 RWMS access tubes provide data only on changes in water contents at depth greater than about $3 \mathrm{~m}(10 \mathrm{ft})$ due to the presence of thick surface casings and cement structures that cannot be logged with accuracy.

\subsection{Biota Monitoring}

On January 15, 2003, DOE O 450.1, “Environmental Protection Program,” was approved. This new order replaced DOE O 5400.1 and added specific requirements for the protection of other natural resources including biota, and to evaluate the potential impacts to biota in the vicinity of 
DOE activities. To demonstrate compliance with these requirements, a DOE technical standard, “A Graded Approach for Evaluating Radiation Doses to Aquatic and Terrestrial Biota” (DOE-STD-1153-2002) was developed by the DOE's Biota Dose Assessment Committee. This standard describes a graded approach for evaluating radiation doses to biota and set the following dose limits that, based on current scientific understanding, are protective of populations of biota:

- $\quad$ Dose limit to aquatic animals = $1 \mathrm{rad} /$ day (10 milligray/day)

- Dose limit to terrestrial plants = $1 \mathrm{rad} /$ day (10 milligray/day)

- Dose limit to terrestrial animals $=0.1 \mathrm{rad} / \mathrm{day}(1 \mathrm{milligray} / \mathrm{day})$

Monitoring of radionuclides in biota are done to evaluate potential dose to biota, and to humans consuming game animals, and to evaluate the possible transport of radionuclides from waste disposal areas.

Biota monitoring consists of sampling vegetation for analyses including tritium, gamma-emitting radionuclides, and transuranics. If radionuclide concentrations in vegetation are high, wild game animals may be sampled. Vegetation sampling may be limited year to year, depending on rainfall and waste cover operations during operational closure. Vegetation from, on, and near waste covers, as well as vegetation from control areas far from waste covers, typically are sampled in mid-summer and analyzed for tritium. Timing of the sampling is important because vegetation is forced to remove soil-water from greater depths (closer to waste) as surface soils dry out in summer. Plant water is extracted from the vegetation samples by room temperature vacuum distillation and analyzed by liquid scintillation for tritium. Animals (and soil from animal burrows) will be monitored for radionuclides if warranted by increasing tritium concentration trends in vegetation or if animal burrows on or near waste covers are observed in significant numbers.

\subsection{Groundwater Monitoring}

Groundwater monitoring is not currently conducted at the Area 3 RWMS. Mixed waste disposal unit U-3ax/bl requires groundwater monitoring under Title 40 CFR 264. However, NDEP has approved a groundwater exemption under Title 40 CFR 264 for the U-3ax/bl disposal unit.

\subsection{Meteorology Monitoring}

The meteorology monitoring program is maintained by operating a two-level meteorology tower at the Area 3 RWMS (Figure 3.1). In addition to fulfilling basic regulatory requirements for meteorology monitoring in DOE O 450.1, the meteorology monitoring program is designed to include measurements of components of the surface energy balance for calculation of PET using the Penman equation (Doorenbos and Pruitt, 1977). PET calculations are an important component of the water balance estimates of the RWMS.

Meteorological parameters monitored include: 
- Air temperature at two heights

- Relative humidity at two heights

- Wind speed at two heights

- Wind direction at two heights

- Barometric pressure

- Solar radiation

- Precipitation

Meteorology monitoring data are reported in an annual monitoring report (NSTec, 2007c). Details of the RWMS meteorology monitoring activities can be found in NSTec OI-2154.111, “Instructions for Datalogger Monitoring Stations.”

\subsection{Subsidence Monitoring}

Subsidence monitoring consists of routine inspections of operational and final waste covers for subsidence features such as cracks and depressions, ponding, and erosion. When such features are observed, their locations are recorded using a Global Positioning System unit and digital camera, and operations personnel are informed to take corrective action.

Subsidence monitoring of U-3ax/bl is currently conducted by NSTec ER as required by agreement with NDEP. Subsidence monitoring is also conducted monthly at disposal units U-3bh and U-3ah/at where waste is buried to ensure that waste remains covered.

Details of the RWMS subsidence monitoring activities can be found in an annual monitoring report (NSTec, 2007c) and NSTec OI-2154.112, "Subsidence Monitoring at the Radioactive Waste Management Sites.” The effectiveness of subsidence monitoring will be periodically evaluated.

\subsubsection{Data Management}

Auditable and defensible data management practices are used throughout the environmental monitoring planning and execution processes from developing the DQOs bases for the monitoring designs, through reporting and archiving. The systems used vary depending on the type of data being managed and the management needs for the data.

The primary data management mechanisms supporting radiological environmental monitoring are the following:

- The Nevada Test Site (NTS) Routine Radiological Environmental Monitoring Plan (RREMP) (BN, 2003a) - documents application of a modified version of the Environmental Protection Agency's Data Quality Objectives process (EPA, 1994) and is described further in 4.3.1.4. 
- Procedures and Instructions - these categories of documents implement the RREMP, and provide execution direction to employees. This ensures clear and consistent work execution.

- Field Operations documentation - data generated during field activities are entered by personnel in the field in logbooks, notebooks, hardcopy forms, and/or electronic forms loaded on a laptop or tablet PC. Field data may subsequently be entered or transferred to an electronic data management system.

- Measurement data - these data cover a variety of types:

o Vadose and meteorological data are downloaded remotely via cellular communications.

o Environmental TLDs (ETLDs) are processed by the NSTec Radiological Control Department and the data provided in electronic form.

o Analytical Laboratory data are produced from analyses of samples collected under the RREMP, and are provided in hardcopy and electronic format.

o All data are processed through quality reviews determined necessary to ensure the validity of the data for their intended use.

- All RWMS monitoring data are managed in an electronic data management system. An Environmental Integrated Data Management System is currently used to manage ETLDs and laboratory generated data. An Oracle ${ }^{\mathrm{TM}}$-based relational database management system used for the comprehensive management and processing of environmental data. The Environmental Integrated Data Management System ensures consistency and promotes advanced planning, while providing a central repository for all unclassified environmental data.

- $\quad$ Monitoring Reports - data are presented in reports as required by Code of Federal Regulations, Department of Energy Orders and Directives, or as otherwise determined necessary.

- Archiving - all data are archived as required, and in a manner (hardcopy and/or electronic) that allows for retrieval.

\subsubsection{Data Evaluation and Data Reporting}

Evaluation of all monitoring data is conducted routinely (minimum once per year), and conclusions of those evaluations are incorporated into one or all of the applicable annual data reports including the Nevada Test Site Environmental Report (NSTec, 2006); the NESHAP report (NSTec, 2007e); and the Annual Waste Management Monitoring Report (NSTec, 2007c). Examples of review performance documents include:

- OI-2154.117, “Verification, Validation, and Data Review of Environmental Technical Services Data Stored in the Bechtel Environmental Integrated Data Management System Database.”

- OI-2154.457, “Radioanalytical Data Verification and Validation” 
- OI-2154.458, “Organic Data Verification and Validation”

- OI-2154.459, “Inorganic Data Verification and Validation”

The NSTec performance documents describing preparation of the NESHAP report and NTSER (also referred to as Annual Site Environmental Report) include:

- Organization Instruction OI-2154.105, "Development of the Annual National Emission Standards for Hazardous Air Pollutants (NESHAPS) Report for the NTS and Offsite Dose Assessment”

- Company Directive CD-B500.001, “Preparation of the Annual Site Environmental Report”

\subsubsection{Organizational Instructions}

The OIs required for routine monitoring include:

- OI-2154.102, "Preparing and Sampling Routine Radiological Environmental Monitoring Plan for Airborne Particulates”

- OI-2154.103, “Tritiated Water Vapor Sampling”

- OI-2154.106, “Neutron Moisture Logging”

- OI-2154.107, "Radon Monitoring Using the E-PERM System”

- OI-2154.108, “Instructions for Area 5 RWMS Groundwater Well Preparation and Groundwater Sampling.”

- OI-2154.109, “Radiation Monitoring Using Thermoluminescent Dosimeters”

- OI-2154.110, “Biota Sampling and Sample Preparation for Animals and Vegetation”

- OI-2154.111, “Instructions for Datalogger Monitoring Stations”

\subsubsection{Quality Assurance}

The RREMP is designed to ensure satisfying the quality assurance requirements of 10 CFR 830 Subpart A, and DOE Order 414.1C.

The RREMP QAASP specifies the sampling, analytical, quality assurance, and quality control procedures for obtaining technically defensible data of acceptable quality to satisfy the project objectives. The QAASP includes guidance for data verification, validation, and quality 
assessment. Detailed QAASPs for air, water, biota, and direct radiation media can be found in Appendices A through D of the RREMP (BN, 2003).

\subsubsection{Final Closure/Institutional Care}

Monitoring activities during the final closure and post-closure period are expected to be reduced and limited to:

- Air monitoring for atmospheric tritium

- Vadose zone monitoring of waste covers and lysimeter facilities

- Biota monitoring for tritium

- Subsidence monitoring

The decision to continue or terminate any monitoring activities during the post-closure period will be based on PA modeling, assessment of monitoring results against conceptual models, uncertainty and sensitivity analysis as well as the evaluation of the past monitoring records for future trends in the data. Monitoring for the closed mixed-waste unit U-3ax/bl will continue for a time period according to conditions negotiated with the NDEP.

\subsubsection{Data Management}

A database similar to the Environmental Integrated Data Management System is expected to be used for the comprehensive management and processing of environmental data during post closure period. Details of such a data management system will be presented in the final closure plan.

\subsubsection{Data Evaluation and Data Reporting}

Frequency of data evaluation and reporting for the post-closure care period will depend upon the monitoring program to be implemented in the final closure plan.

\subsubsection{Organization Instructions}

The organizational instructions required for routine monitoring during the post-closure period will be similar to the ones presented in Section 3.3.1.3, and will be presented in the final closure plan.

\subsubsection{Quality Assurance}

The currently applicable QAASPs will remain in effect during the post-closure care period. 


\subsection{CLOSURE SCHEDULE}

As operations continue at the Area 3 RWMS, this closure plan will be updated to reflect the most current operational features that must be considered during closure. The schedule for final closure of the facility will be developed in 2025.

A schedule for post-closure monitoring and maintenance activities will also be developed as part of the final closure plan. Monitoring for the closed mixed-waste unit U-3ax/bl will continue for a period of time according to conditions negotiated with the NDEP. 
This Page Intentionally Left Blank 


\subsection{REFERENCES}

Allred, D. M., D. M. Beck, and C. D. Jorgensen, 1963. "Biotic Communities of the Nevada Test Site.” Brigham Young University Science Bulletin, Biological Series 2(2), No. 2.

Andraski, B. J., 1997. "Soil-Water Movement Under Natural-Site and Waste-Site Conditions: A Multiple-Year Field Study in the Mojave Desert, Nevada.” Water Resources Research Vol. 33 No. 8: pp 1901-1916.

Barker, L., 1997. Alternative Evaluation Study: Methods to Mitigate/Accommodate Subsidence for the Radioactive Waste Management Sites at the Nevada Test Site, Nye County, Nevada, with Special Focus on Disposal Unit U-3ax/bl. Bechtel Nevada. September 1997.

Battis, J. D., 1978. Geophysical Studies for Missile Basin; Seismic Risk Studies in the Western United States. TI-ALEX(02)-FSR-78-01. Texas Instruments, Inc., Houston, Texas.

Beatley, J. C., 1976. Vascular Plants of the Nevada Test Site and Central-Southern Nevada; Ecology and Geographic Distributions. TID-26881. U.S. Energy Research and Development Administration, Division of Biomedical and Environmental Research.

Bechtel Nevada (BN), 2003. Nevada Test Site Routine Radiological Environmental Monitoring Plan. DOE/NV/11718--804. Report to U.S. Department of Energy, National Nuclear Security Administration Nevada Site Office, Las Vegas, Nevada. June 2003.

-, 1999. Characterization Report for Corrective Action Unit 110: Area 3 U-3ax/bl Disposal Unit Nevada Test Site, Nevada. DOE/NV--580. Report to U.S. Department of Energy, Nevada Operations Office, Las Vegas, Nevada. Environmental Restoration Division, Bechtel Nevada. November 1999.

, 1998a. Geology Report, Area 3 Radioactive Waste Management Site, Nye County, Nevada. DOE/NV/11718--195. Report to U.S. Department of Energy, Nevada Operations Office, Las Vegas, Nevada. January 1998.

1998b. Hydrogeologic Characterization of the Unsaturated Zone at the Area 3 Radioactive Waste Management Site. Volume 1: Data Interpretations. Volume 2: Data. DOE/NV/11718--210. Bechtel Nevada, February 1998.

1998c. Alternative Evaluation Study: Implementing Vadose Zone Monitoring at the Nevada Test Site-Issues Common to All Environmental Programs and Issues Unique to Radioactive Waste Management Sites, November 3-4, 1997. Report to U.S. Department of Energy, Nevada Operations Office, Las Vegas, Nevada. January 1998.

Belcher, W.R. editor, 2004. Death Valley Regional Groundwater Flow System, Nevada and California - Hydrogeologic Framework and Transient Ground-Water Flow Model, U.S. Geological Survey, Scientific Investigations Report 2004-5205. 
Black, P., K. Black, L. Stahl, M. Hooten, T. Stockton, and D. Neptune, 2001. Assessing the Probability of Inadvertent Human Intrusion at the Nevada Test Site Radioactive Waste Management Sites. DOE/NV--593. Report to U.S. Department of Energy, Nevada Operations Office. March 2001.

Blout, D. O., W. S. Birchfiel, D. P. Hammermeister, K. A. Zukosky, and K. D. Donnelson, 1995. Site Characterization Data from Area 5 Science Boreholes, NTS, Nye County, Nevada. DOE/NV/11432--170. Reynolds Electrical \& Engineering Co., Inc. February 1995.

Burns, H. H., 1999. “Vadose Zone Monitoring System for the Savannah River Site Low-Level Radioactive Waste Disposal Trenches.” 11th Technical Information Exchange Conference, October 26-28, 1999, Las Vegas, Nevada.

Campbell, K. W., 1980. Seismic Hazard Analysis for the Nevada Test Site Spent Reactor Fuel Test Site. UCRL-15620. Lawrence Livermore Laboratory, Livermore, California.

Castor, S. B., S. C. Feldman, and T. J. Vingley, 1990. Mineral Evaluation of the Yucca Mountain Addition, Nye County, Nevada. Open-File Report 90-4, Nevada Bureau of Mines and Geology, Reno, Nevada.

Chapman, J. B., 1994. Classification of Groundwater at the Nevada Test Site. DOE/NV/10845--16. Desert Research Institute, Las Vegas, Nevada.

Cochran, J. R., W. E. Beyeler, D. A. Brosseau, L. H. Brush, T. J. Brown, S. H. Conrad, P. A. Davis, T. Ehrhorn, T. Feeney, B. Fogleman, D. P. Gallegos, R. Haaker, D. Kalinina, L. L. Price, D. P. Thomas, and S. Wirth, 2001. Compliance Assessment for the Transuranic Wastes in the Greater Confinement Disposal Boreholes at the Nevada Test Site. Volume 2: Performance Assessment (Version 2.0). Sandia Report SAND20012977. Sandia National Laboratories. September 2001.

Cole, J.C. and P.H. Cashman, 1999. Structural Relationships of Pre-Tertiary Rocks in the Nevada Test Site Region, Southern Nevada, U.S. Geological Survey Professional Paper 1607.

Cole, J. C., R. R. Wahl, and M. R. Hudson, 1989. "Structural Relations Within the Paleozoic Basement of Mine Mountain Block; Implications for Interpretation of Gravity Data in Yucca Flat, Nevada Test Site.” In: C. W. Olsen and J. A. Carter (eds.), Proceedings of the Fifth Symposium on Containment of Underground Nuclear Explosions. Lawrence Livermore National Laboratory Proceedings, CONF-850953, p. 431-456.

Crowe, B. M., and V. Yucel, 2007. Institutional Control Policies and Implementation for the Area 5 and Area 3 Radioactive Waste Management Sites. April 2007. (Unpublished manuscript). 
Crowe, B. M., P. Wallmann, and L. M. Bowker, 1998a. "Probabilistic Modeling of Volcanism Data: Final Volcanic Hazard Studies for the Yucca Mountain Site.” In: Perry, F., B. M. Crowe, G. A. Valentine, J. Geissman, L. McFadden, S. Wells, M. Murrell, J. Poths, and L. Bowker, Volcanism Synthesis Report. Los Alamos National Laboratory, Los Alamos, New Mexico.

Crowe, B., W. Hansen, R. Waters, M. Sully, and D. Levitt, 1998b. The Consequences of Disposal of Low-level Radioactive Waste from the Fernald Environmental Management Project: Report of the DOE/Nevada Independent Panel. LA-13453-MS. Los Alamos National Laboratory, Los Alamos, New Mexico.

Crowe, B. M., 1990. “Basaltic Episodes of the Yucca Mountain Region.” In Proceedings, Highlevel Radioactive Waste Management, International Conference, Las Vegas, Nevada. American Nuclear Society, La Grange, Illinois, p.65-73.

Crowe, B. M., M. T. Vaniman, and W. J., Carr, 1983. Status of Volcanic Hazard Studies for the Nevada Nuclear Waste Storage Investigation. LA-9325-MS. Los Alamos National Laboratory, Los Alamos, New Mexico.

Desotell, L. T., D. B. Hudson, D. Anderson, V. Yucel, G. Shott, G.L. Pyles and J.T. Carilli. 2007. "Performance of Evapotranspirative Covers Under Enhanced Precipitation: Preliminary Data,” In WM'07 Conference, February 26-30, 2007, Tuscon, Arizona. DOE/NV/25946--079. NSTec, Las Vegas, Nevada.

Desotell, L.T., D. B. Hudson, V. Yucel, and J. T. Carilli, 2006. "Use of Long-Term Lysimeter Data in Support of Shallow Land Waste Disposal Cover Design.” In WM'06 Conference, February 26 - March 2, 2006, Tucson Arizona. DOE/NV/11718--1148. Bechtel Nevada. Las Vegas, Nevada.

Dockery-Ander, H. A., 1984. Rotation of Late Cenozoic Extensional Stress, Yucca Flat Region, Nevada Test Site, Nevada. PhD dissertation. Rice University, Houston, Texas.

DOE (U.S. Department of Energy), 2005. Integrated Closure and Monitoring Plan for the Area 3 and Area 5 Radioactive Waste Management Sites at the Nevada Test Site. DOE/NV/11718-449-REV2. June 2005.

DOE, 2002. Memorandum from EM-43 to Kathleen Carlson, Manager, Nevada Operations Office. "Disposal Authorization for the Nevada Test Site Area 3 Radioactive Waste Management Site - Submittal of Revised Performance Assessment and Composite Analysis dated December 17, 2001.” August 2, 2002. 2000a. Closure Plan for Corrective Action Unit 110: Area 3 RWMS U-3ax/bl Disposal Site, Nevada Test Site, Nevada. DOE/NV--647. Environmental Restoration. August 2000.

1999a. Format and Content Guide for U.S. Department of Energy Low-Level Waste Disposal Facility Closure Plans. Unpublished DOE guidance. November 10, 1999. 
— 1999b. 200-BP-1 Prototype Barrier Treatability Test Report. DOE/RL-99-11, Rev. 0. August 1999.

— Assessment of the Underground Test Area, Nevada Test Site, Nevada,” DOE/NV-477, Las Vegas, NV.

— 1996. Final Environmental Impact Statement for the Nevada Test Site and Off-Site Locations in the State of Nevada. DOE/EIS-0243. Nevada Operations Office, Las Vegas, Nevada.

—, 1991. Environmental Regulatory Guide for Radiological Effluent Monitoring and Environmental Surveillance. DOE/EH-0173T. January 1991.

DOE Order 435.1, “Radioactive Waste Management.” U.S. Department of Energy, Washington, D.C., August 28, 2001.

DOE G 435.1-1, “General Responsibilities and Requirements.” U.S. Department of Energy, Washington, D.C., July 9, 1999.

DOE M 435.1-1, “Radioactive Waste Management Manual.” U.S. Department of Energy, Washington, D.C., June 19, 2001.

DOE Order 450.1, “Environmental Protection Program,” U.S. Department of Energy, Washington, D.C., January 15, 2003. 5400.5, Change 2. "Radiation Protection of the Public and the Environment." U.S. Department of Energy, Washington, D.C., January 7, 1993.

Doorenbos, J., and W. O. Pruitt, 1977. Guidelines for Predicting Crop Water Requirements. FAO Irrigation and Drainage Paper No. 24, 2nd ed., FAO Rome, Italy. 156 p.

Drellack, S. L., Jr., 1994. “An Introduction to NTS Geology and Geophysical Log Characteristics.” Raytheon Services Nevada. May 1994.

Drellack, S. L., and P. H. Thompson, 1990. Selected Stratigraphic Data for Drillholes in LANL Use Areas of Yucca Flat. DOE/NV/10322--39. U.S. Department of Energy Report.

Dwyer, S. F., 2001. “Finding a Better Cover.” Civil Engineering. January 2001, pp. 58-63.

Dwyer, S. F., 1998. “Alternative Landfill Covers Pass the Test.” America Society of Civil Engineers. Civil Engineering, September 1998. 
Elletson, L. W., and K. R. Johnejack, 1995. Waste Inventory Report for the U-3ax/bl Disposal Unit at the NTS. DOE/NV/11432-193. REECo, December 1995.

EPA (U.S. Environmental Protection Agency), 1994. "Guidance for the Data Quality Objectives Process.” EPA A/G-4. Quality Assurance Management Staff, Washington, D.C.

FFACO (Federal Facilities Agreement and Consent Order), 2004. Prepared by the Nevada Division of Environmental Protection, the U.S. Department of Energy, and the U.S. Department of Defense.

Frizzell, J. A., Jr., and J. Shulters, 1990. Geologic Map of the Nevada Test Site, Southern Nevada. U.S. Geological Survey Miscellaneous Investigations Series Map I-2046, scale $1: 100,000$.

Garside, L. J., R. H. Hess, K. L. Fleming, and B. S. Weider, 1988. “Oil and Gas Developments in Nevada.” Nevada Bureau of Mines and Geology Bulletin 104, Reno, Nevada.

Goering, T., 1999. "Use of a Close-Coupled Landfill Cover and Vadose Zone Monitoring System to Reduce Long-Term Groundwater Monitoring Costs.” 11th Technical Information Exchange Conference, October 26-28, 1999, Las Vegas, Nevada.

Gonzales J. L., S. L. Drellack, and M. T. Townsend, 1998. Descriptive narrative for the Hydrogeologic Model at the Yucca Flat Corrective Area Unit. An interim report. Bechtel Nevada, Las Vegas, Nevada.

Gonzales J. L. and S. L. Drellack, 1999. “Addendum to the Descriptive Narrative for the Hydrogeologic Model of the Yucca Flat Corrective Area Unit: Northern Extension,” Bechtel Nevada, Las Vegas, Nevada.

Gustafson, D. L., S. E. Rawlinson, and J. J. Miller, 1993. "Summary of Natural Resources That Potentially Influence Human Intrusion at the Area 5 RWMS, DOE/NTS, Nye County, Nevada.” Raytheon Services Nevada. August 1993.

Hale, G. S., D. A. Trudeau, and C. S. Savard, 1995. "Water-Level Data from Wells and Test Holes Through 1991, and Potentiometric Contours as of 1991 for Yucca Flat, Nevada Test Site, Nye County, Nevada,” Water-Resources Investigations Report 95-4177, U.S. Geological Survey, Denver, Colorado.

Hannon, R. M., and H. L. McKague, 1975. An Examination of the Geology and Seismology Associated with Area 410 at the Nevada Test Site. UCRL-51830. Lawrence Livermore National Laboratory, Livermore, California.

Hansen, D. J., and W. K. Ostler, 2003. Rooting Characteristics of Vegetation Near Areas 3 and 5 Radioactive Waste Management Sites at the Nevada Test Site. DOE/NV/11718--595. Report to National Nuclear Security Administration Nevada Site Office, Las Vegas, Nevada. September 2003. 
Hunter, R. B., 1992. Status of the Flora and Fauna on the Nevada Test Site, 1989-1991. Unpublished manuscript.

IT Corporation, 1996a. Groundwater Flow Model Documentation Package (Phase I Data Analysis Documentation, Volume VI). Prepared for DOE/NV. Las Vegas, Nevada.

—, 1996b. Hydrologic Parameters Data Documentation Package (Phase I Data Analysis Documentation, Volume IV). ITLV/10972-181. Las Vegas, Nevada.

Kearl, P. M., 1982. "Water Transport in Desert Alluvial Soil.” Desert Research Institute, Bioresources Center Publication 45024.

Keefer, W. R., J. W. Whitney, and E. M. Taylor, 2004. Quaternary Paleoseismology and Stratigraphy of the Yucca Mountain Area, Nevada, U. S. Geological Survey Professional Paper 1689. Las Vegas, Nevada.

Laczniak, R. J., J. C. Cole, D. A. Sawyer, and D. A. Trudeau, 1996. Summary of Hydrogeologic Controls on Ground-Water Flow at the Nevada Test Site, Nye County, Nevada. USGS. Water-Resources Investigations Report 96-4109.

Levitt, D. G., M. J. Sully, B. L. Dozier, and C. F. Lohrstorfer, 1999. “Determining the Performance of an Arid Zone Radioactive Waste Site Through Site Characterization, Modeling and Monitoring." Proceedings of the Waste Management '99 Conference, Tucson, Arizona.

Levitt, D. G., B. L. Dozier, J. M. Dixon and L. T. Desotell, 1998. "The Influence of Climate and Vegetation as Factors for Waste Cover Design.” Proceedings of the DOE Nevada Vadose Zone Monitoring Workshop, September 24-25, 1998, Las Vegas, Nevada.

Metcalf, L. A., 1983. “A Preliminary Review and Summary of the Potential for Tectonic, Seismic, and Volcanic Activity at the Nevada Test Site Defense Waste Disposal Site.” Desert Research Institute, Water Resources Center Publication 45029. DOE Report DOE/NV/01162--7.

Miller, J. J., 1996. Flood Assessment for the Area 3 Radioactive Waste Management Site, Nevada Test Site, Nye County, Nevada. Bechtel Nevada report to U.S. Department of Energy, Nevada Operations Office.

Nevada State Demographer's Office, 2005. Nevada County Population Estimates, July 1, 1990 to July 1, 2005, Includes Cities and Towns. Prepared for the Nevada Department of Taxation in conjunction with the Nevada Small Business Development Center. Electronic copy extracted April 10, 2006, from URL: http://www.nsbdc.org/demographer/pubs/images/NVpopul05.pdf 
NNSA/NSO (National Nuclear Security Administration Nevada Site Office), 2006. Nevada Test Site Waste Acceptance Criteria. DOE/NV--325, Rev. 6-02. June 2006.

NNSA/NV, (National Nuclear Security Administration Nevada Operations Office), 2001. Closure Report for Corrective Action Unit 110: Area 3 RWMS U-3ax/bl Disposal Unit, Nevada Test Site, Nevada. DOE/NV--733. Environmental Restoration Division. June 2001.

NSTec, 2007a. Maintenance Plan for Performance Assessments and Composite Analyses of the Area 3 and Area 5 Radioactive Waste Management Sites at the Nevada Test Site. DOE/NV/25946 - 091. Report to U.S. Department of Energy, National Nuclear Security Administration Nevada Site Office, Las Vegas, Nevada. January 2007.

_ 2007b. Characterization Report Area 3 Radioactive Waste Management Site Nevada Test Site, Nevada. DOE/NV/25946-080. Report to U.S. Department of Energy, National Nuclear Security Administration Nevada Site Office, Las Vegas, Nevada. March 2007

, 2007c Nevada Test Site 2006 Waste Management Monitoring Report: Area 3 and Area 5 Radioactive Waste Management Sites, Nevada Test Site. DOE/NV/25946--225. Report to U.S. Department of Energy, National Nuclear Security Administration Nevada Site Office, Las Vegas, Nevada. June 2007.

, 2007d. 2006 Annual Summary Report for the Area 3 and Area 5 Radioactive Waste Management Sites, Nevada Test Site, Nye County, Nevada: Review of the Performance Assessments and Composite Analyses. DOE/NV/25946--135. Report to U.S. Department of Energy, National Nuclear Security Administration Nevada Site Office, Las Vegas, Nevada. March 2007.

, 2007e. National Emissions Standards for Hazardous Air Pollutants Calendar Year 2006. DOE/NV/25946--171. Report to U.S. Department of Energy, National Nuclear Security Administration Nevada Site Office, Las Vegas, Nevada. June 2007.

— 2006. Nevada Test Site Environmental Report 2005. DOE/NV/11718--1214. Report to U.S. Department of Energy, National Nuclear Security Administration Nevada Site Office, Las Vegas, Nevada. October 2006.

Obi, C. M., G. J. Shott, C. J. Muller, and L. E. Barker, 1996. Preliminary Estimates of Future Waste Subsidence, Hydrogeologic Impact, and Contaminant Concentrations for Area 3 RWMS Disposal Units at the NTS. Bechtel Nevada. October 1996.

O’Farrell, T. P., and L.A. Emery, 1976. Ecology of the Nevada Test Site: A Narrative Summary and Annotated Bibliography. NVO-167. National Technical Information Service Publication, Springfield, Virginia.

O’Farrell, T. P., and R. O. Gilbert, 1975. “Transport of Radioactive Materials by Jackrabbits on the Hanford Reservation.” Health Physics, Vol. 29, p. 9-15. 
Ostler, W. K., D. J. Hansen, D. C. Anderson, and D. B. Hall, 2000. Classification of Vegetation on the Nevada Test Site. DOE/NV/11718--477. Report to the U.S. Department of Energy, Nevada Operations Office, Las Vegas, Nevada. December 2000.

REECo (Reynolds Electrical \& Engineering Co., Inc.), 1994. Site Characterization and Monitoring Data from Area 5 Pilot Wells, NTS, Nye County, Nevada. DOE/NV/11432--74. February 1994.

- 1993a. Hydrogeologic Data for Existing Excavations at the Area 5 RWMS, NTS, Nye County, Nevada. DOE/NV/11432-40. December 1993. , 1993b. Hydrogeologic Data for Science Trench Boreholes at the Area 5 RWMS, NTS, Nye County, Nevada. December 1993.

— 1980. Nevada Test Site Radioactive Waste Management Consolidation Report. Waste Management Department, Reynolds Electrical \& Engineering Co., Inc., Las Vegas, Nevada.

— 1968. Nevada Test Site Waste Disposal Records. Waste Management Department, Reynolds Electrical \& Engineering Company, Inc., Las Vegas, Nevada.

Reno, R. L., and L. C. Pippin, 1985. “An Archeological Reconnaissance of Yucca Flat, Nye County, Nevada.” Desert Research Institute Technical Report No. 35, Las Vegas, Nevada.

Richard-Haggard, K., 1983. Economic Potential of Alternative Land and Natural Resources Uses at the Nevada Test Site, Nye County, NV. Desert Research Institute Publication No. 45030, Las Vegas, Nevada.

Rogers, A. M., D. M. Perkins, and F. A. McKeon, 1977. A Preliminary Assessment of the Seismic Hazard of the Nevada Test Site Region. Bulletin of the Seismology Society of America, Vol. 67, p. 1587-1606.

SAIC/DRI (Science Applications International Corporation/Desert Research Institute), 1991. Special Nevada Report, U.S. Air Force, Tactical Weapons Center, Office of Public Affairs, Nellis Air Force Base, Las Vegas, Nevada.

Schmeltzer, J. S., L. E. Barker, and D. O. Blout, 1996. Site Characterization Data from the U-3ax/bl Exploratory Boreholes at the NTS. DOE/NV/11718--003. Bechtel Nevada. April 1996.

Shott, G. J., V. Yucel, M. J. Sully, L. E. Barker, S. E. Rawlinson, and B. A. Moore, 2000. Performance Assessment/Composite Analysis for the Area 3 RWMS at the NTS, Nye County, Nevada. Revision 2.1. DOE/NV--491. Bechtel Nevada. July 2000. 
Shott, G. J., L. E. Barker, S. E. Rawlinson, M. J. Sully, and B. A. Moore, 1998. Performance Assessment for the Area 5 Radioactive Waste Management Site at the Nevada Test Site, Nye County, Nevada. Revision 2.1. DOE/NV/11718--176. June 1998.

Trexler, J. H., J. C. Cole, and P. H. Cashman, 1996. “Middle Devonian-Mississippian Stratigraphy on and near the Nevada Test Site: Implications for Hydrocarbon Potential." American Association of Petroleum Geologists Bulletin, Vol. 80, p. 1736-1762.

Tyler, S. W., J. B. Chapman, S. H. Conrad, D. P. Hammermeister, D. O. Blout, J. J. Miller, M. J. Sully, and J. M Ginanni, 1996. "Soil-Water Flux in the Southern Great Basin, United States: Temporal and Spatial Variations over the Last 120,000 Years.” Water Resources Research 32(6):1481-1499.

Walker, G. E., 1962. “Groundwater in the Climax Stock, Nevada Test Site, Nye County, Nevada,” U.S. Geological Survey Trace Element Investigations Report TEI-813, 48pp., Washington, DC.

Wallace, A., E. M. Romney, and R. B. Hunter, 1980. “The Challenge of a Desert: Revegetation of Disturbed Desert Lands.” Great Basin Naturalist Memoirs. No. 4. Brigham Young University.

Wallace, A., and E. M. Romney, 1972. Radioecology and Ecophysiology of Desert Plants at the Nevada Test Site. National Technical Information Service Publication TID-25954, Springfield, Virginia.

Wills, C. A. and W. K. Ostler, 2001. Ecology of the Nevada Test Site: An Annotated Bibliography, With Narrative Summary, Keyword Index, and Species List. DOE/NV/11718_594. December 2001.

Test Site.” Hydrology of Nuclear Test Sites. U.S. Geological Survey Professional Paper 712-C.

Winkel, V. K., J. P. Angerer, D. B. Hall, M. W. Fariss, and K. R. Johnejack, 1995 . Plant and Burrowing Animal Characteristics. Integrated Closure Program for the Area 3 and Area 5 RWMSs, NTS. EG\&G and REECo, March 1995.

Winograd, I. J., and W. Thordarson, 1975. Hydrogeologic and Hydrochemical Framework, South-Central Great Basin, Nevada-California, with Special Reference to the Nevada Test Site. U. S. Geological Survey Professional Paper 712-C.

Wirth, S., T. Brown, and W. Beyler, 1999. Native Plant Uptake Model for Radioactive Waste Disposal Areas at the Nevada Test Site. SAND98-1789. Sandia National Laboratories Report.

Wong, I. G., S. K. Pezzopane, N. A. Abrahamson, R. K. Green, J. I. Sun, and R. C. Quittmeyer. "A Preliminary Assessment of Earthquake Ground Shaking Hazard at Yucca Mountain, 
Nevada and Implications to the Las Vegas Region” Conference on Seismic Hazards in the Las Vegas Region. Las Vegas, Nevada. 14-16 November 1996.

Young, M. H., P. J. Wierenga, A. W. Warrick, L. L. Hofmann, S. A. Musil, M. Yao, C. J. Mai, Z. Zou, and B. R. Scanlon, 1999. Results of Field Studies at the Maricopa Environmental Monitoring Site, Arizona. NUREG/CR-5694. U.S. Nuclear Regulatory Commission. June 1999. 


\section{APPENDIX: Title II Engineering Cover Design}


This Page Intentionally Left Blank

Appendix- 2 


\title{
APPENDIX: TITLE II ENGINEERING COVER DESIGN
}

\author{
05120-003-133-T1 Title Sheet \\ 05120-033-133-C1 Civil Symbols, Notes and Legend \\ 05120-033-133-C2 Vicinity Map \\ 05120-033-133-C3 Existing Site Plan \\ 05120-033-133-C4 Proposed Site Plan \\ 05120-033-133-C5 U-3ah/at Grading Plan \\ 05120-033-133-C6 U-3ah/at Grading Sections \\ 05120-033-133-C7 U-3bh Grading Plan \\ 05120-033-133-C8 U-3bh Grading Sections \\ 05120-033-133-C9 Borrow Pit Grading Plan \\ 05120-033-133-C10 Borrow pit Grading Sections
}


This Page Intentionally Left Blank

Appendix- 4 